\title{
التبليس في المسائل الأصولية دراسة نظرية تطبيقية
}

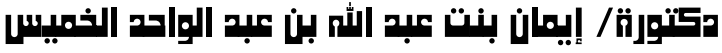

قسم أصول الفقه- كلية الثريعة

جامعة الإمام محمد بن سعود الإسلامية

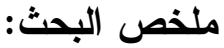

المسائل الأصولية بطبيعتها الجدلية منطوية على جملة من المصطلحات التـي

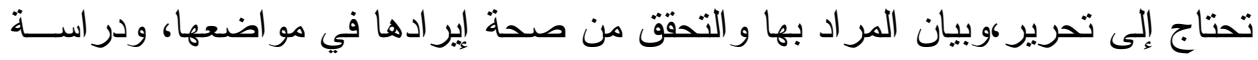

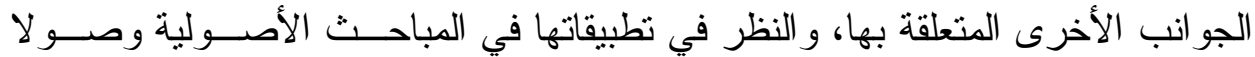
لبيان مدى تأثير ها.

ومن تلك المصطلحات مصطلح (التلبيس)، وقد أردت بهذا البحث در اسة هــذات

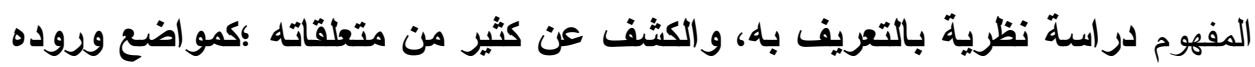

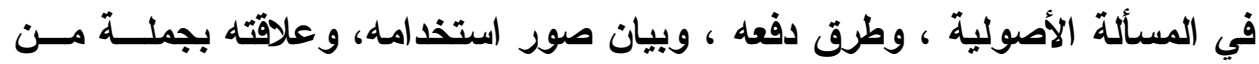
المصطلحات الأخرى ذات العلاقة وغير ذلتك.

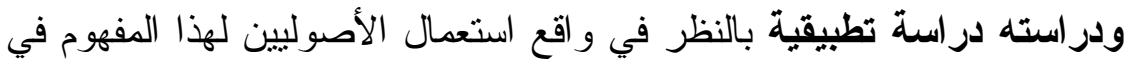

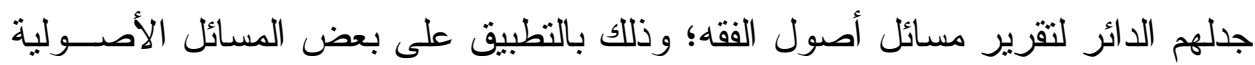
التي ظهر فيها هذا المفهوم، و التحقق من دليله وصحة إير اده. 


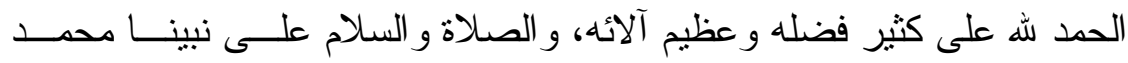

خاتم رسله و أنبيائه. وبعد:

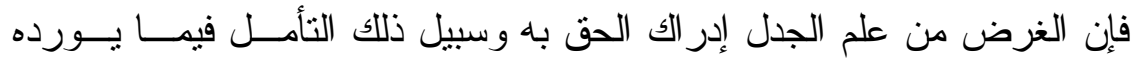

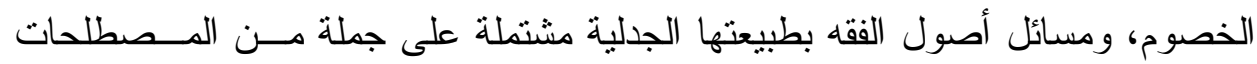

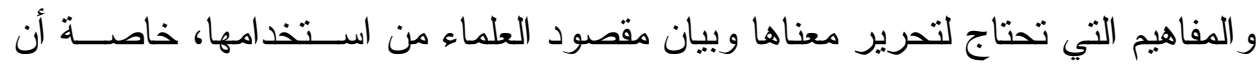

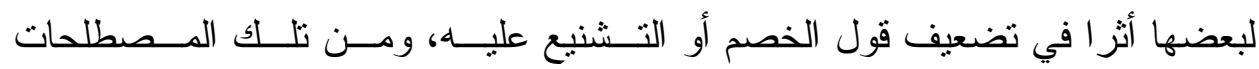

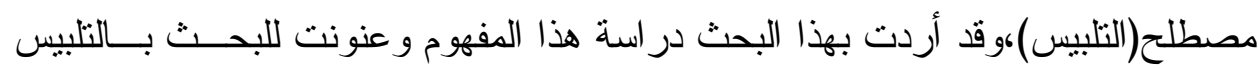

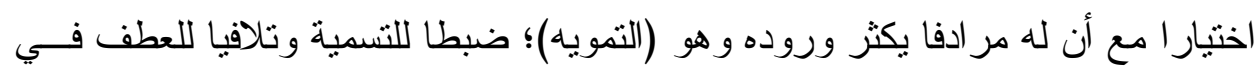

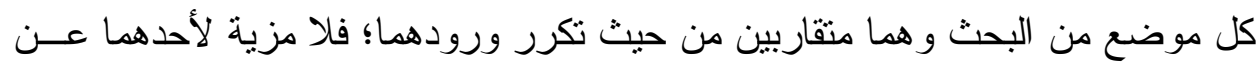
الآخر من حيث كثرة الاستعمال.

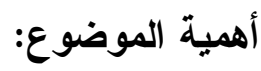

تظهر أهمية الموضوع في أمور منها:

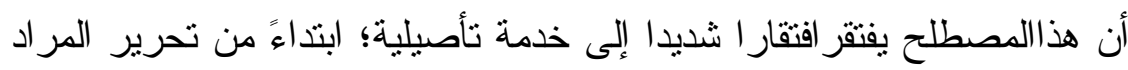

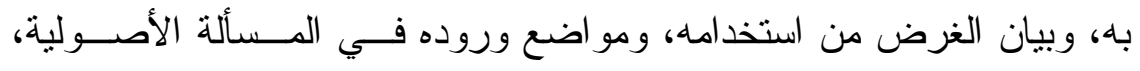
وبيان صوره، وطرق كثفه و الرد عليه.

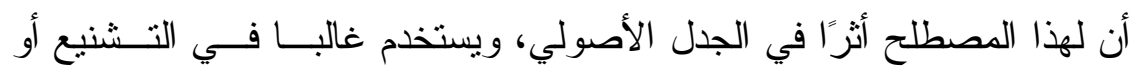

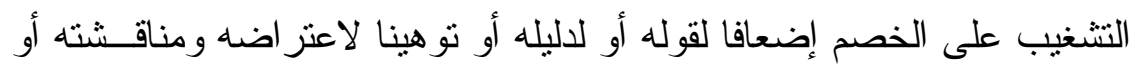
نحو ذلك فالحاجة قائمة لتحقيق القول في سلامة استعماله و الحاجة إليه.

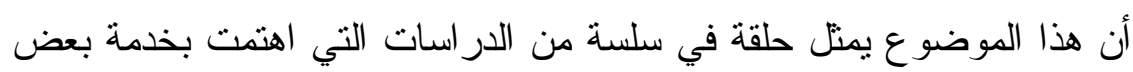

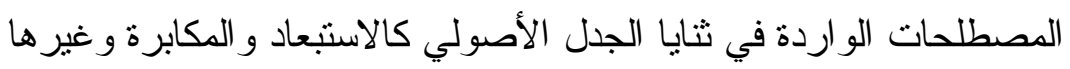

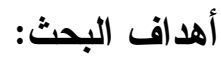
يهدف هذا البحث إلى أمور هي:

در اسة الجوانب النظرية التأصيلية لمفهوم التلبيس؛ بالتعريف به، وبيان علافته

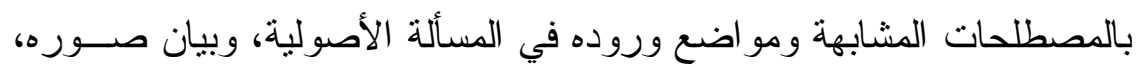
و الغرض من استخدامه ونحو ذلك. 
النظر في واقع استعمال الأصوليين لهذا المفهوم في جدلهم الدائر لتقرير مسائل

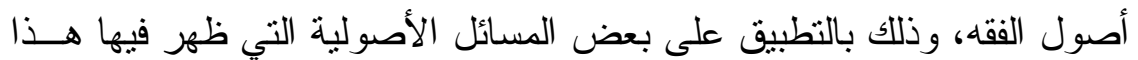

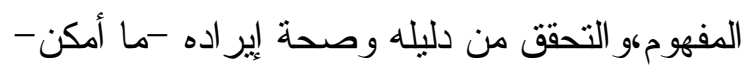

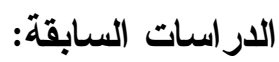

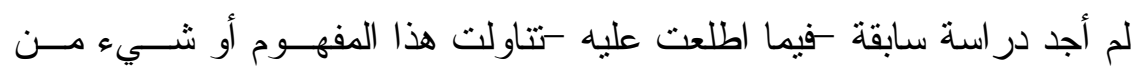
مر ادفاته، و أقرب الموضو عات التي وقعت عليها حين التحري عن الدراســات الــسابقة

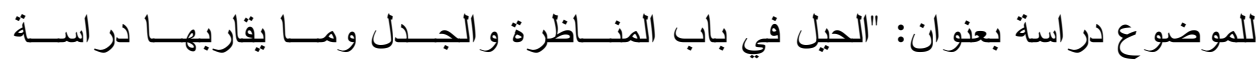

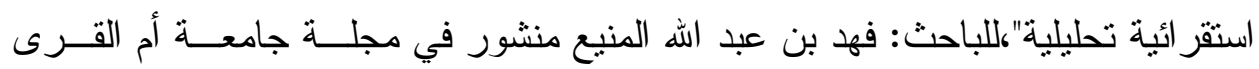

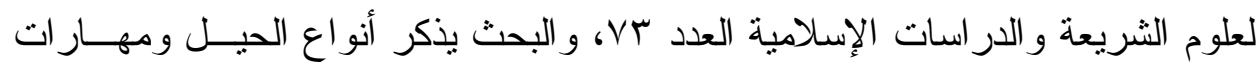

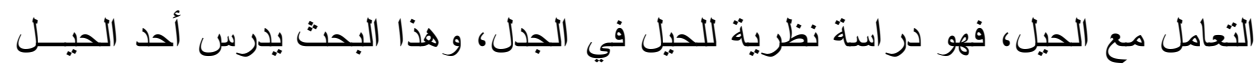

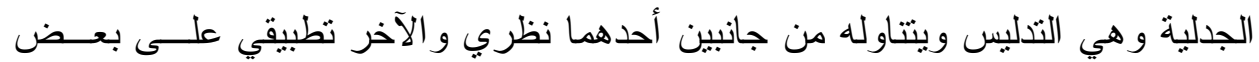
مسائل أصول الفقه.

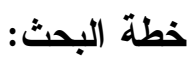
يتألف هذا البحث من مقدمة، ومبحثين، وخاتمة. المقدمة، وفيها:

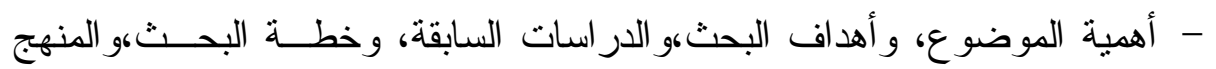

$$
\text { المتبع. }
$$

المبحث الأول: الدراسة النظرية لمفهوم التلبيس،وفيه ستة مطالب:

$$
\text { - المطلب الأول:تعريف التلبيس لغة و اصطلاحها. }
$$
- المطلب الثاني:العلاقة بين التلبيس و الألفاظ ذات العلاقة. - المطلب الثالث:الغرض من التلبيس. - المطلب الرابع:مو اضع ورود مصطلح التلبيس. - المطلب الخامس: صور التلبيس. - المطلب السادس: طرق كثف التلبيس. • المبحث الثاني: دراسة تطبيقية لمصطلح التلبيس في بعض المسائل الأصولية، وفيه خمسة مطالب: - المطلب الأول: إحداث قول ثالث بعد انقر اض العصر 
- المطلب الثاني: ما تفيده الواو العاطفة. - المطلب الثالث:توجه الأمر للمعدوم. - المطلب الرابع:هل الحكم في حق كل شخص ما أدى إليه اجتهاده؟ - المطلب الخامس: اعتبار المصير إلى الإجماع تقليدا. • • • • •

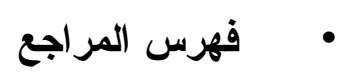
منهج البحث: سرت في البحث على منهج يتلخص فيما يأتي: (1) (1) الاعتماد على المصادر الأصلية في البحث.

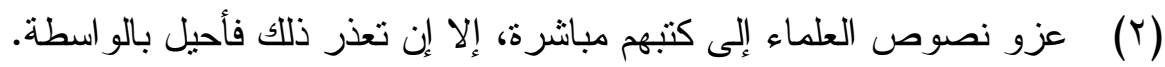

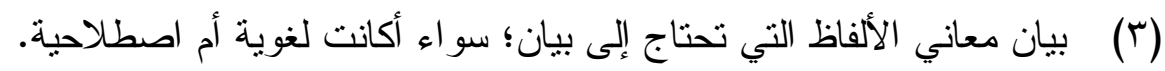

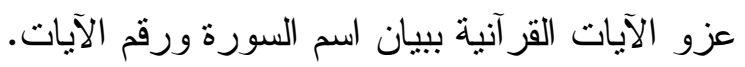

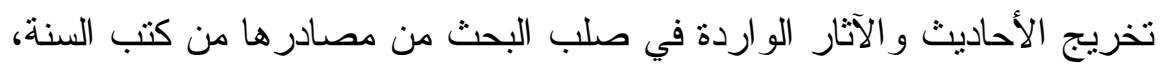

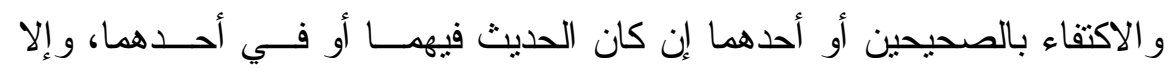
خرّجتها من المصادر الأخرى المعتمدة، مع ذكر ما قاله أهل الحديث فيها. وأسال الله التوفيق والسداد، إنه سميع مجيب، ولا حول ولا قوة إلا بالله. 
المبحث الأول: الاراسة النظرية لمفهوم التلبيس

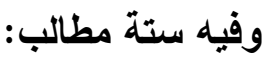

المطلب الأول: تعريف التلبيس لغة ولة واصطلاحا أولا: التبيس لغة:تفعيل من لبَّس يلبَّس تلبيسا.

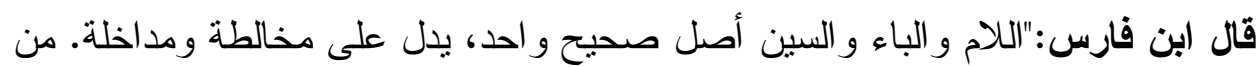

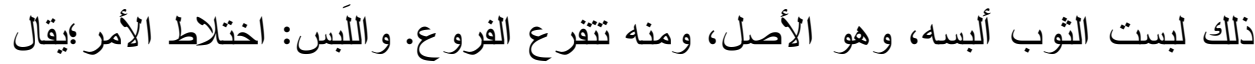

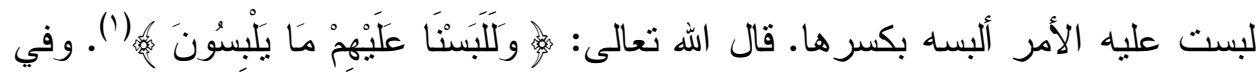
الأمر لُبسة، أي ليس بو اضَح" (؟).

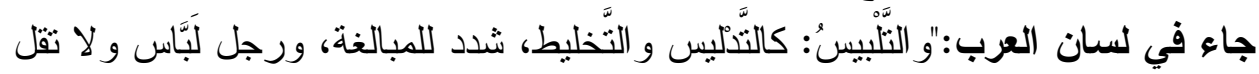

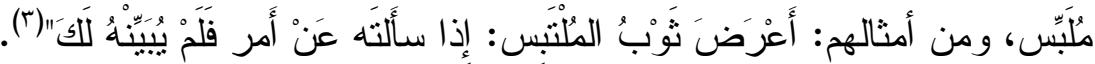
فالتلبيس في اللغة هو التخليط، و إدخال الأمور ببعضها، و وعدم الإيضاح. ثانيا: التلبيس اصطلاحا:

عرف الجرجاني التلبيس بأنه:"ستر الحقيقة و إظهار ها بخلاف ما هي عليه"(؛) وعرفه المناوي بأنه:"التخليط و الإشكال"(•)

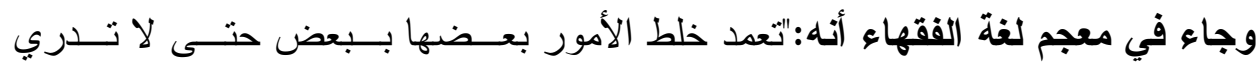
حقبقتها"(T).

و هذه التعريفات مع تقاربها لا تخرج بالتلبيس عن المعنى اللغوي المتقدم.

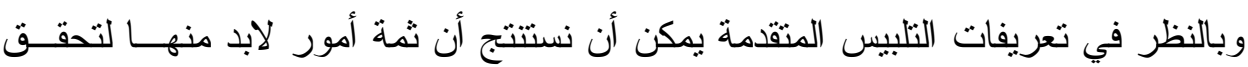
التلبيس وهي: وبطر

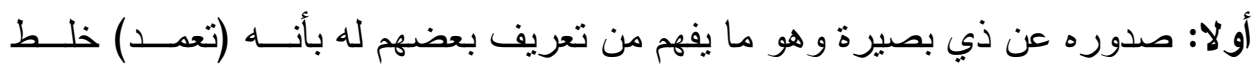

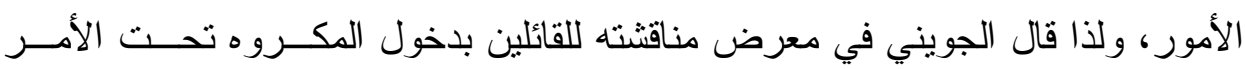

$$
\begin{aligned}
& \text { سورة الأنعام آية } 9 .
\end{aligned}
$$

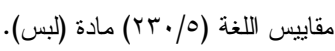

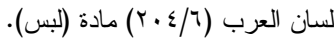

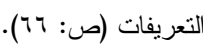

$$
\begin{aligned}
& \text { التوقيف على مهمات التعاريف (ص: ^ • ( ). } \\
& \text { معجم لغة الفقهاء (ص: ؟ ؟1). }
\end{aligned}
$$




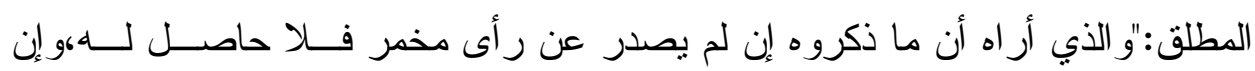
صدر هذا القول عن ذي بصيرة فهو تلبيس" ('). ثانيا: خلط الأمور بعضها ببعض أو ستر الحقيقة.

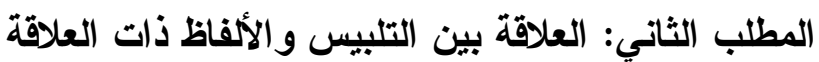
أولا:العلاقة بين التلبيس و التمويه: التمويه في اللغة:

جاء في لسان العرب:"مَوَّهَ الثيء: طلاه بذهب أو بفضة وما تحت ذلك شبه أو نحسـاس

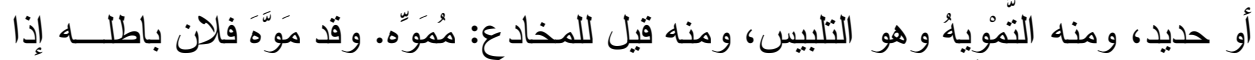

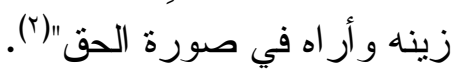

والتمويه اصطلاحا لا يخرج عن معناه اللغوي ولذا قال الكفوي:"هــو إلبــاس صــــورة

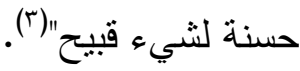
فمما تقدم يظهر أن التدليس و التمويه من المنز ادفات؛ولذا نجد بعض الأصوليين يعطفون

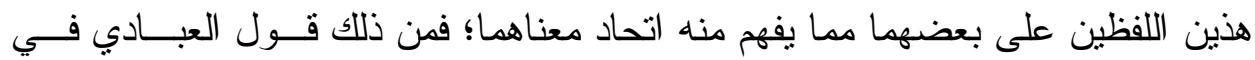

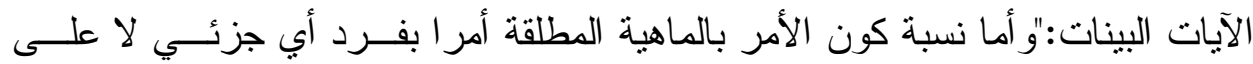

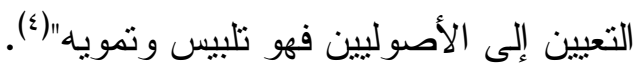
ثانيا:العلاقة بين التلبيس والاحتيال:

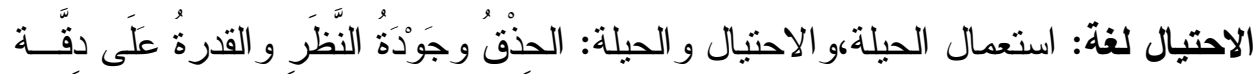
التصرُّف (ن).

وفي الاصطلاح: ما يتوصل به إلى مقصود بطريق خفي (آ). وقد ذكر ابن القيم أنه غلب على الحيلة في العرف استعمالها في سلوك الطرق الخفيــة التي يتوصل بها الرجل إلى حصول غرضه بحيث لا يتفطن له إلا بنوع مــن الـــــاء

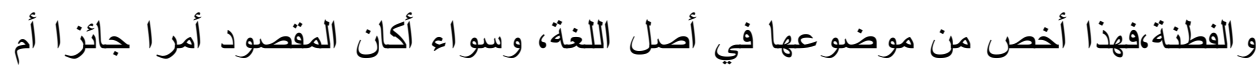

$$
\begin{aligned}
& \text { البرهان في أصول الفقه (1/1 + 1). }
\end{aligned}
$$

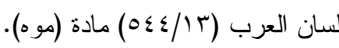

$$
\begin{aligned}
& \text { الكليات (ص: ع آب). } \\
& \text { الآيات البينات (r/r • (1). } \\
& \text { لسان العرب (1) 110/1) ). }
\end{aligned}
$$

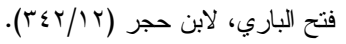




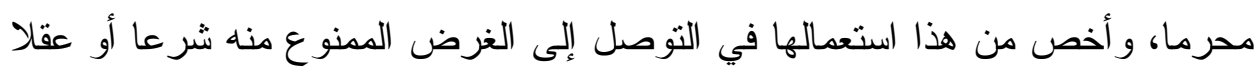

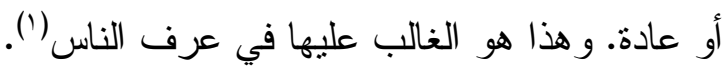

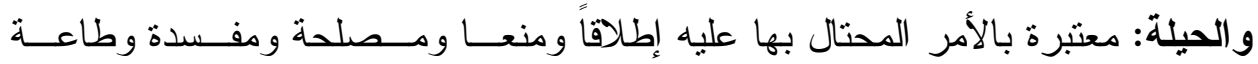

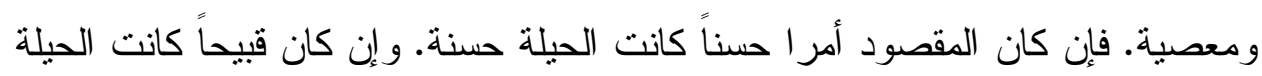
قبيحة. و إن كان طاعة وقربة كانت الحيلة عليه كذلك. وإن كانت التهان معصية وفسوقاً كانت الحيلة عليه كنللك (؟).

و التلبيس على ما تقدم هو :"تعدد خلط الأمور بعضها ببعض حتى لا تــدري حقبقتهــا"

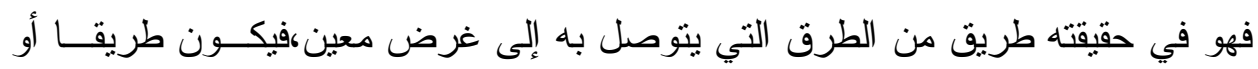

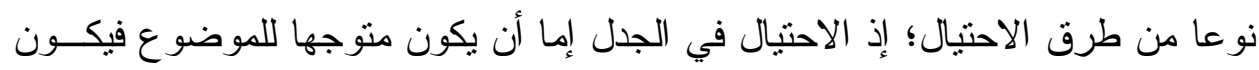

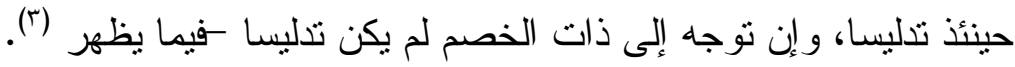
ثالثا:العلاقة بين التلبيس و والمغالطة:

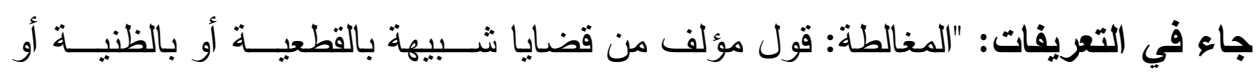

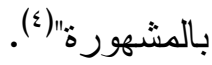

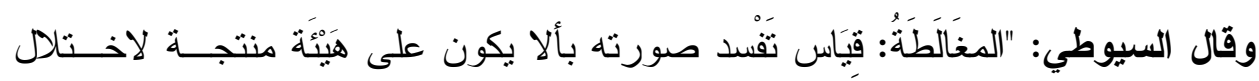

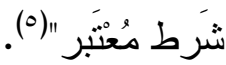
فالمغالطة في حقيقتها قياس فاسد مركب من مقدمات شبيهة بالحق، وبالتأمل في تعريف

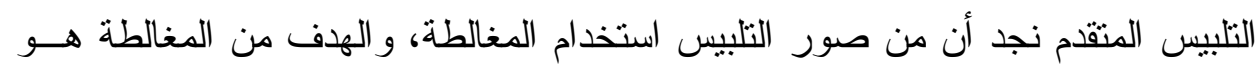
التلبيس على الخصم(7). 
المطلب الثالث: الغزض من التلبيس قد تتعدد الأغراض من التلبيس على الخصم، ومن تلك الأغر اض: سوء المقصد من الجدل.

قال ابن عقيل ذاكرا المقاصد من الجدل:"ويجعلا -أي السائل و المسؤول-قصدهما أحســ

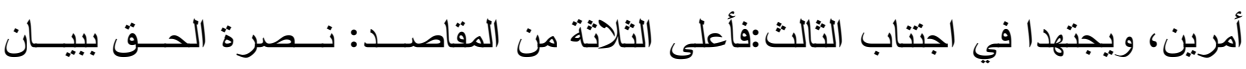
الحجة، ودحض الباطل بإبطال الثبهة؛ لتكون كلمة الله هي العليــا، و الثتـاني: الإدمـــان

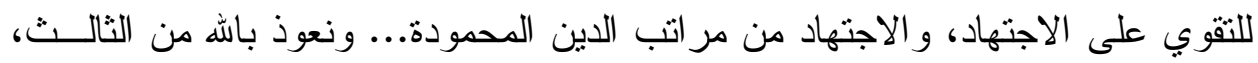
وهو : المغالبة وبيان الفر اهة على الخصم و الترجح عليه في الطريقة"(').

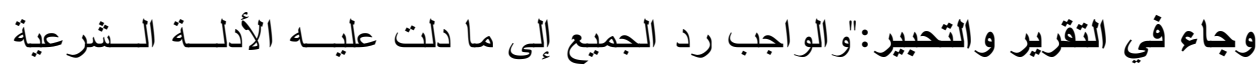

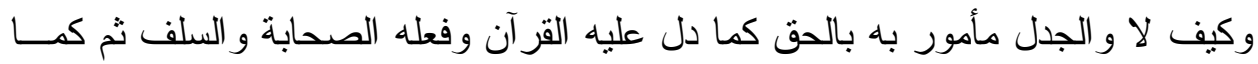

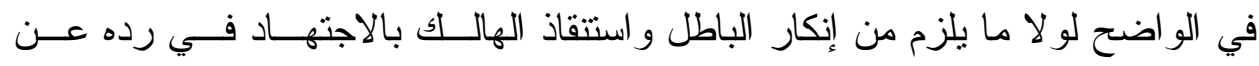

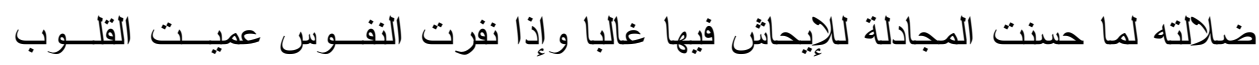

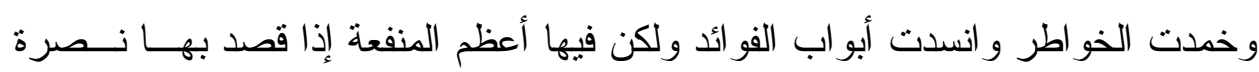

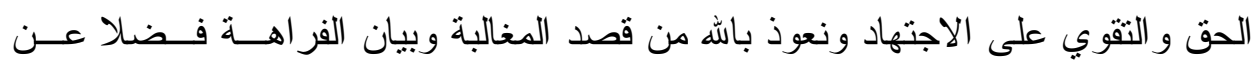

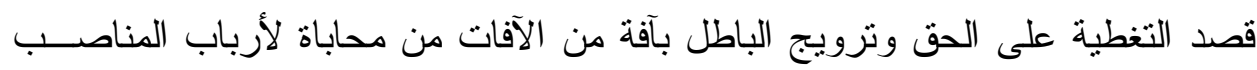

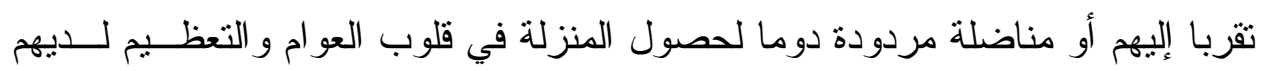
إلى غير ذلك من القصود المحرمة أو المكروهة"(؟). فمتى ساء المقصد من الجدل جاء أحد الخصمين بالتدليس استغفالا للآخر و استجهالا له. قال الغزالي بعد ذكره إحدى طرق التلبيس:"وسبيل من يريد التلبيس إهمال المقدمة التي التلبيس تحتها استغفالا للخصم و استجهالا له" ("). وقال ابن قدامة: "قد يكون الإهمال للمقدمة الأولى، وقد يكون للثانية. وقد تترك إحــدى

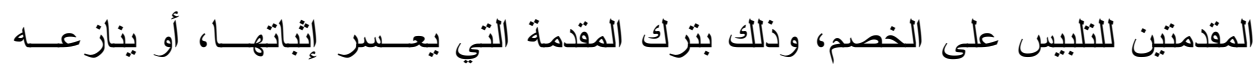

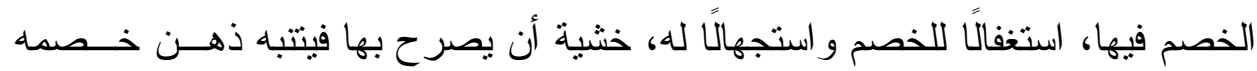

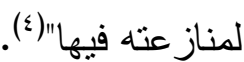

$$
\begin{aligned}
& \text { الو اضح في أصول الفقه (1)/11). }
\end{aligned}
$$

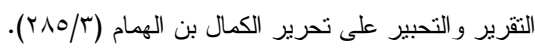

$$
\begin{aligned}
& \text { المستصفى (ص:••؟). } \\
& \text { روضة الناظر وجنة المناظر (هV/I). }
\end{aligned}
$$




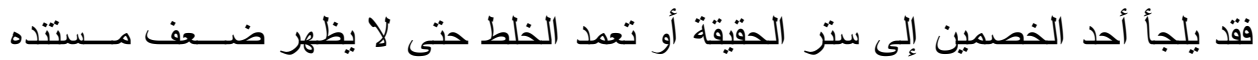
ووهن حجته.

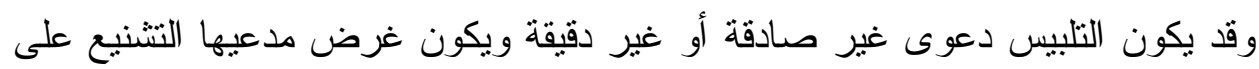

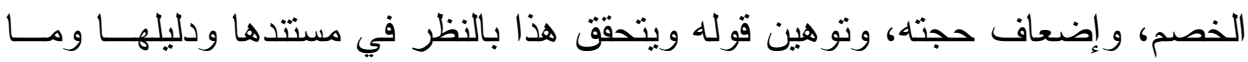
قامت عليه على ما سيأتي في طرق كثف التلبيس. المطلب الرابع: مواضع ورود التلبيس في المسألة الأصولية

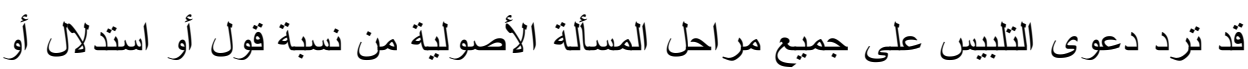
اعتر اض أو مناقشة أو غير ها. فمثال ورودها على نسبة القول: قول الطوفي رحمه الله:" قال القر افي: قال إمام الحرمين في المسائل: لم يقل بالتقليد في الأصول إلا الحنابلة.

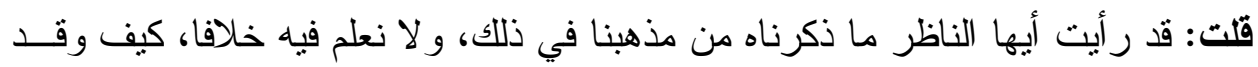

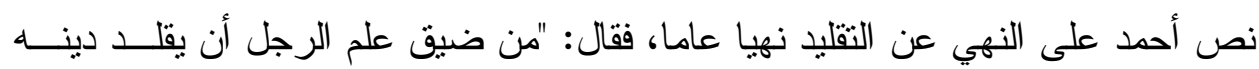

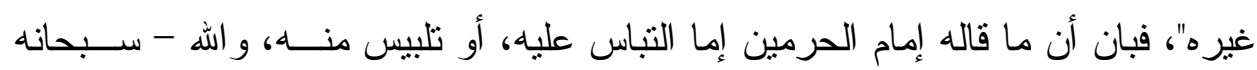

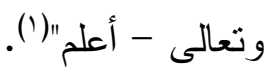
وقول العبادي في الآيات البينات:"وأما نسبة كون الأمر بالماهية المطلقة أمر ا بفــرد أي أي

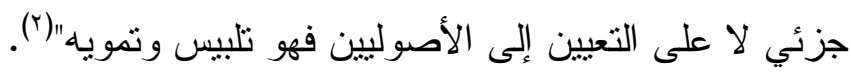
ومن أمثلة وروده في الاستدلال:

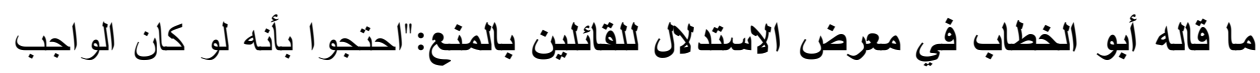

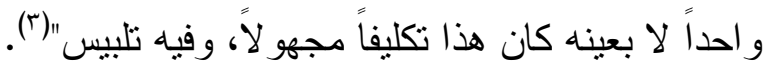
ومثال وروده في المناقشة قول الاسمندي:"فإن قيل: الو اجب فـــي العمومـــات إجمــال

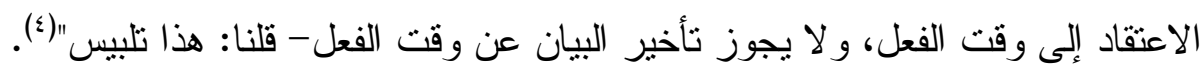

$$
\begin{aligned}
& \text { شرح مختصر الروضة (r/T/Tr). } \\
& \text { الآيات البينات (r/r • ()). }
\end{aligned}
$$

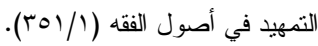

$$
\begin{aligned}
& \text { بذل النظر في الأصول (ص: r.ץ). }
\end{aligned}
$$


وسيأتي معنا الكلام في مزيد من التمنيل على هذا في الجانب التطبيقي من البحث بـإذن اله.

المطلب الخامس: صور التلبيس

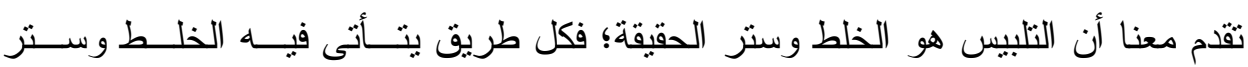
الحقيقة فهو طريق من طرق التلبيس وهذا مما لا ينحصر ، قال الجويني:" وللحذاق مـنـ لهن

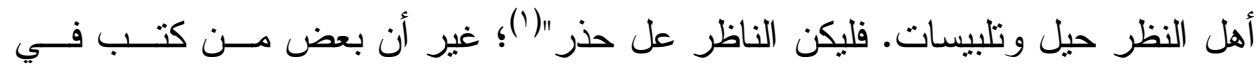
الجدل أثنار إلى شيء من هذه الصور ومن ذللك: استخدام المغالطات، و العبث بمقدمات

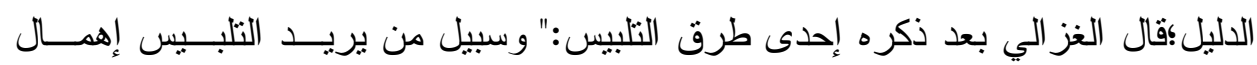
المقدمة التي التلبيس تحتها استغفالا للخصم و استجهالا له" (؟).

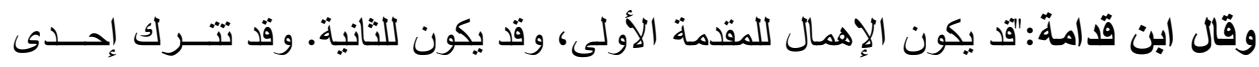

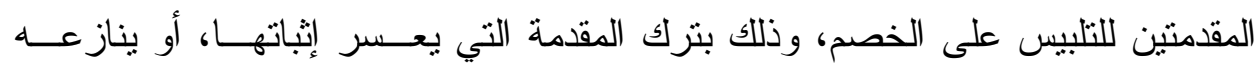

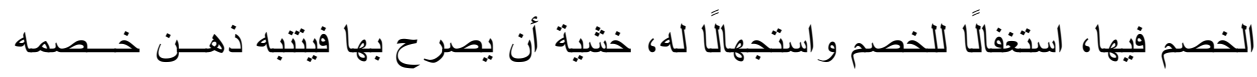

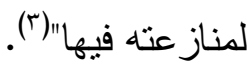

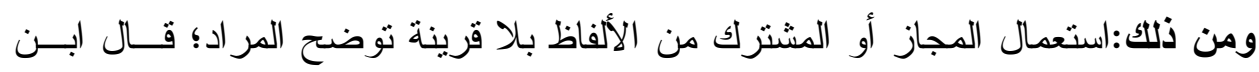

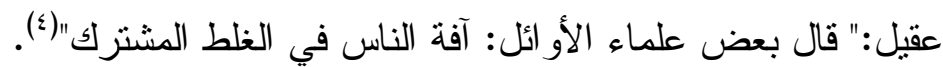

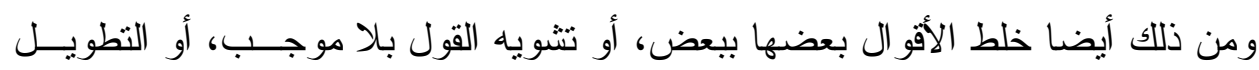

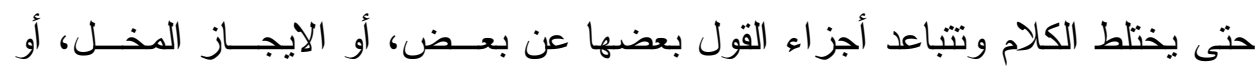

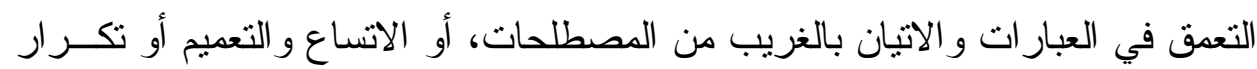

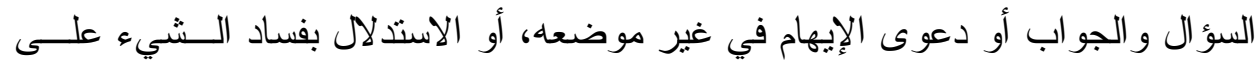

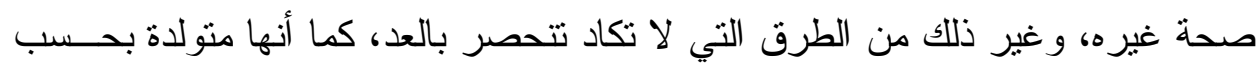
حذق النظار (0).

$$
\begin{aligned}
& \text { الكافية (ص: } 9 \text { (0). }
\end{aligned}
$$

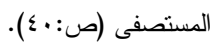

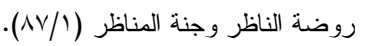

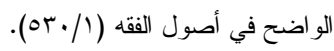

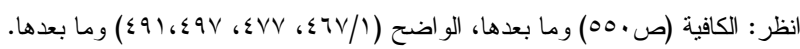


المطلب السادس: طرق كشف التلبيس

يمكن كشف التلبيس بطرق عديدة منها:

أولا:تأمل قول الخصم واستكثاف محل التلبيس وموضع التمويه؛ قال ابن عقيل:"وحاجة

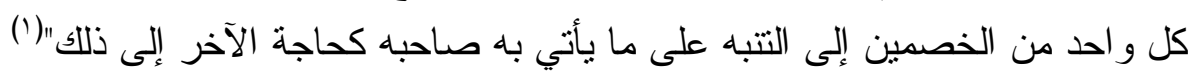

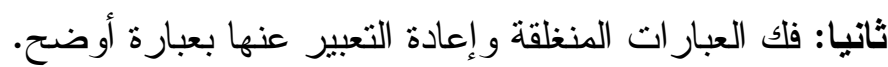

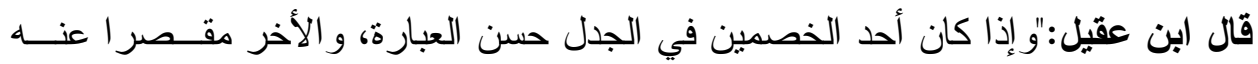

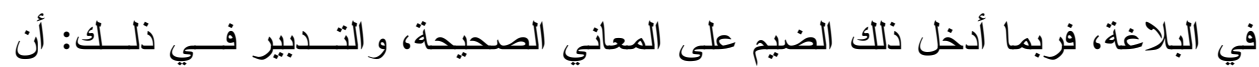
يقصد إلى المعنى الذي قد رتبه صاحبه بعبارته عنه، فيعبر عنه بعبارة أخرى تدل عليه

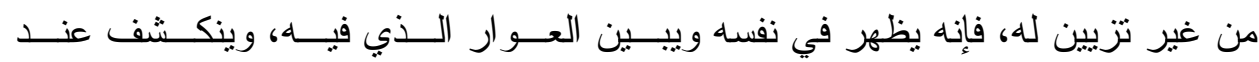

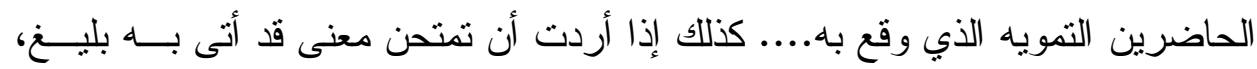

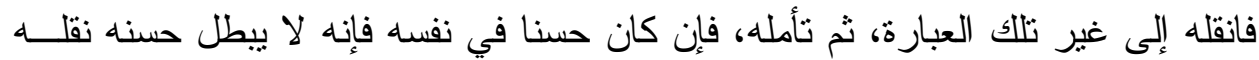

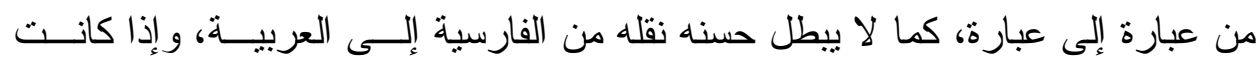

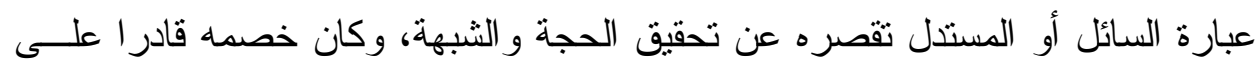

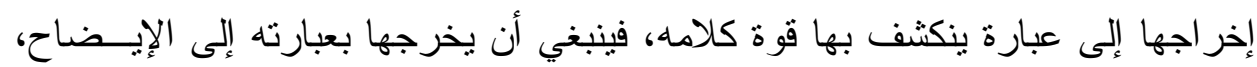

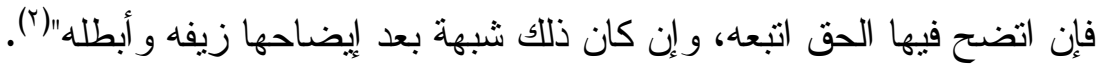

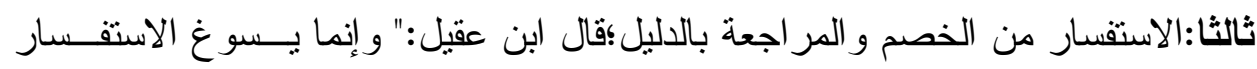

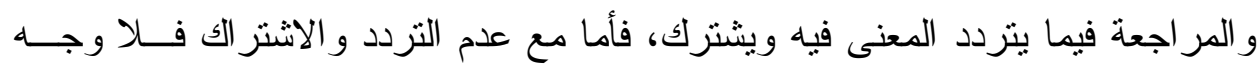

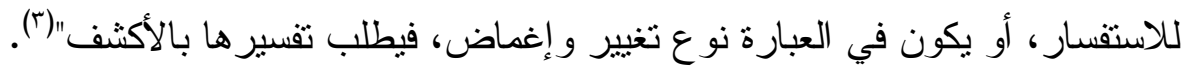
وقال في موضع آخر:" لا سبيل إلى حل شبهة الخصم في الجدل إلا بعد إدر اكها، فلا بد نديز

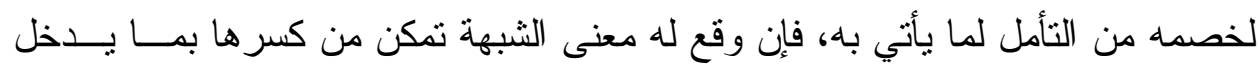

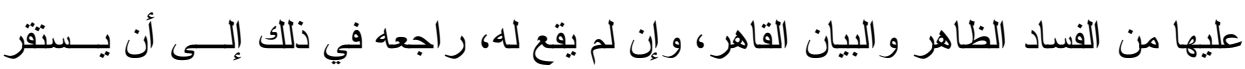

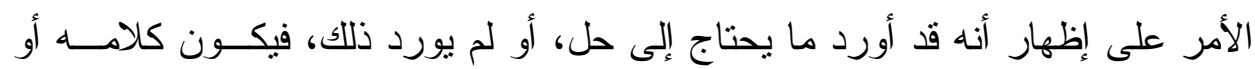

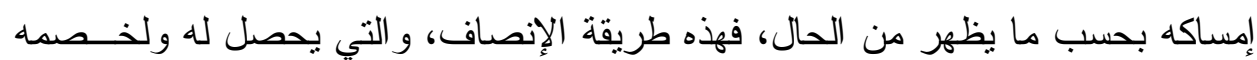

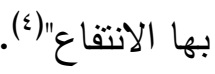

\begin{tabular}{|c|}
\hline الو اضح في أصول الفقه ( /. r ro). \\
\hline الو اضح في أصول الفقه (1/1/019، 019). \\
\hline الو اضح في أصول الفقه ( /9१§). \\
\hline الو اضح في أصول الفقه (CrY/l). \\
\hline
\end{tabular}




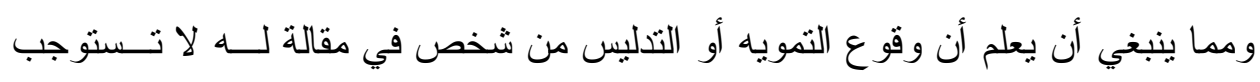

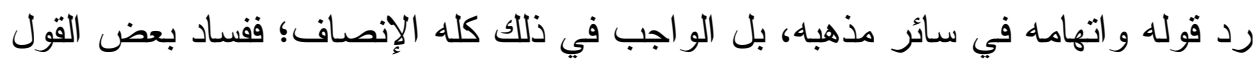
لا يقتضي فساد كله.

قال ابن عقيل: "و إذا كان أحد الخصمين في الجدل قد أخطأ في بعض المذاهب، فاحــر

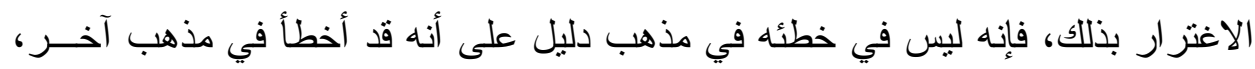

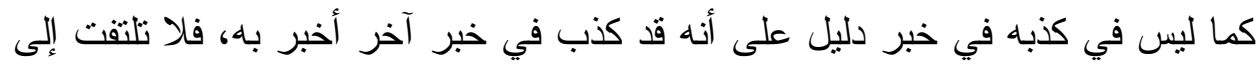

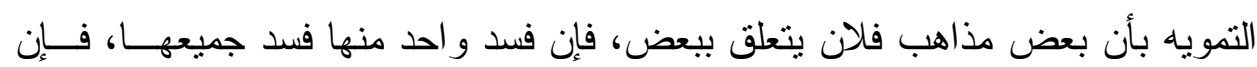

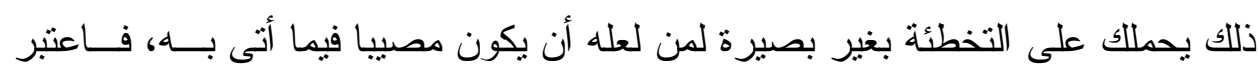

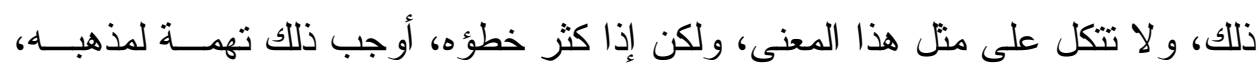
وقلة سكون إلى اختباره، من غير أن يحصل ذللك دليلا على فساده لا محالة"( 'ال. 
المبحث الثاني: دراسة تطبيقية لمصطلح التلبيس في بعض المسائل الأصولية وفيه خمسة مطالب:

المطلب الأول: إحداث قول ثمالث بعد انقر اض العصر : المر اد بانقر اض العصر : - الع

موت المجمعين بعد اتفاقهم على الحكم في الحادثة التي نشأت في عصر هم (').

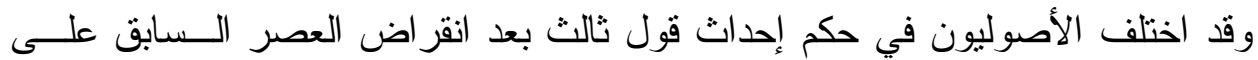

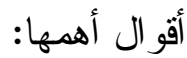

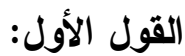
لا يجوز إحداث قول ثالث في المسألة مطلقا.

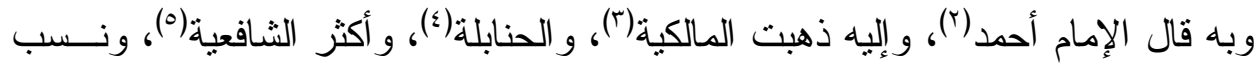
إلى الأكثر (7).

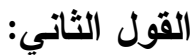

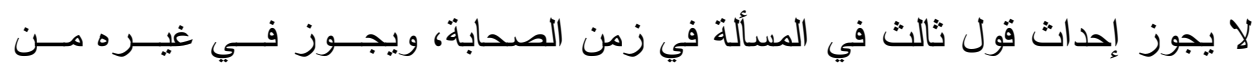
الأزمان.

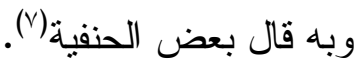

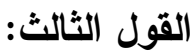

يجوز إن لم برفع شيئا مما أجمع عليه القو لان، ولا يجوز إن رفع مجمعا عليه.

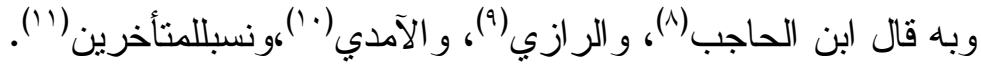

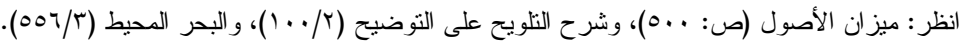

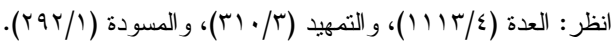

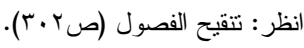

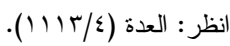

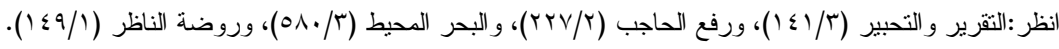

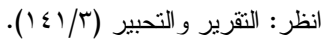

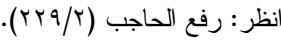

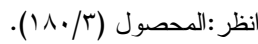

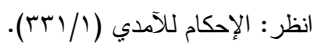

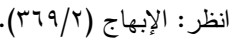




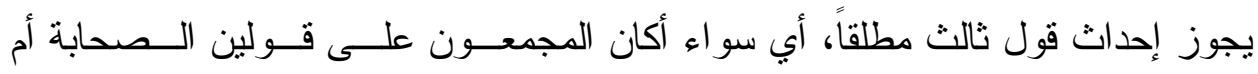
غير هم، وسو اء رفع الثالث مجمعا عليه أم لم يرفع. وبه قال بعض الحنفية(') موضع ورود دعوى التلبيس:

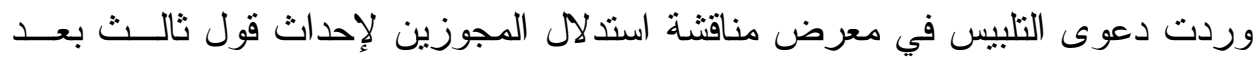

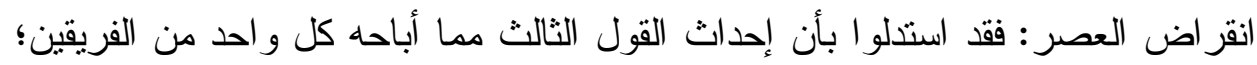
لأن الذي ذهب إلى هذا القول، أباح ترك ذللك القول. و الذي ذهب إلى إلى ذلك القول، أبــاح ترك هذا القول، فإذا ترك القولين فقد نرك ما أباحه الفريقان جميعاً (؟). نوقش:

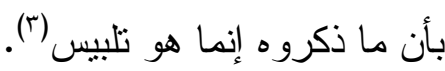

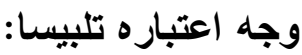

إن الصائرين إلى القولين سوغو ا الخلاف منحصر ا في القولين فقط.

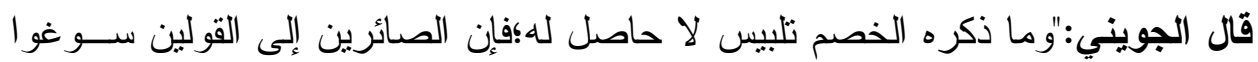

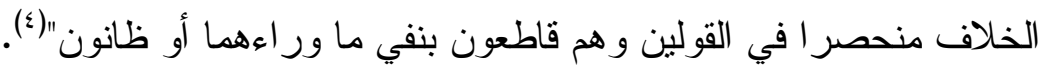

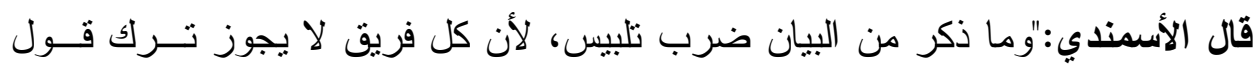

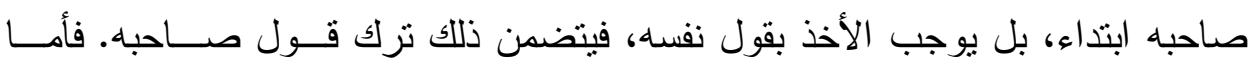
إحداث قول ثالث، فــنزك الأخذ بقوله وقول صاحبه، وقد أجمعو ا على المنع منه" (ه). تحقيق دعوى وجود التلبيس:

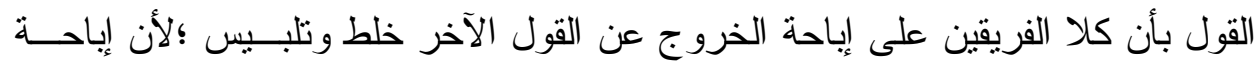

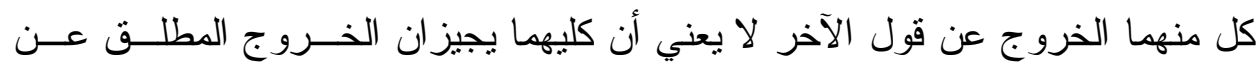

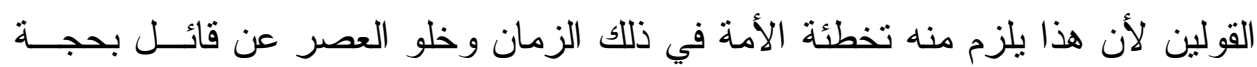
الله، والحق أن العصر قد انقرض على حصر الحق في أحد هذين القولين فهو إجمـــاع

$$
\begin{aligned}
& \text { انظر : النقرير و التحبير (r/r؟ ().). }
\end{aligned}
$$

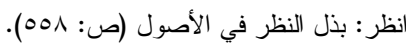

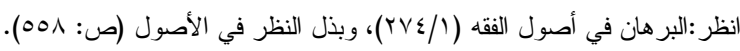

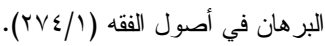

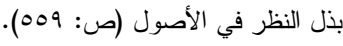


ضمني في أقل أحو اله، فالترك المطلق للقولين مشكل وهو خروج عن هـــا الإجمــاع،

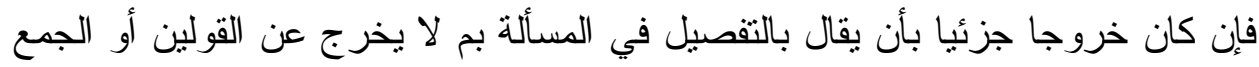
بين القول فلا يعد خروجا فيما يظهر و اله أعلم. المطلب الثاني: ما تفيده الواو العاطفة: اختلف الأصوليون فيما تفيده الواو العاطفة على أفوه القوال:

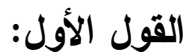

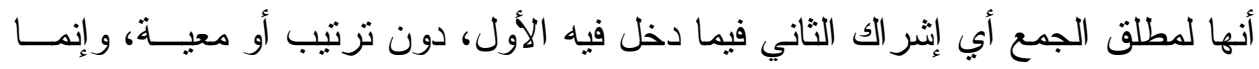
للقدر المشترك بينهم وهو قول جمهور النحويين و الأصوليين (').

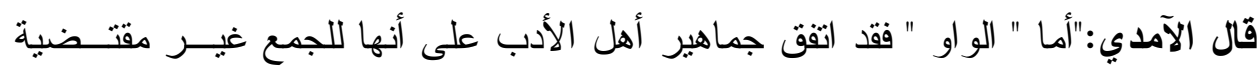
تزتيبا و لا معية"(r)". أنها للتزتيب، نقل هذا القول عن الثافعي (־). القول الثالث:

أنها للمعية،ونسب إلى بعض الحن الحنفية(£). موضع ورود دعوى التلبيس:

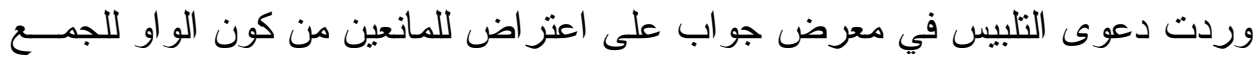

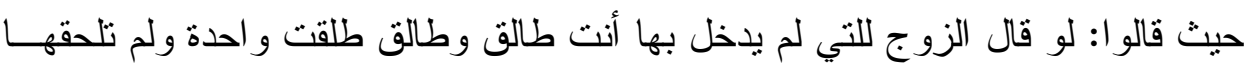

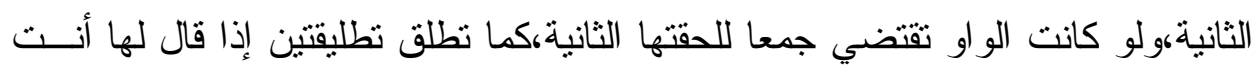
طالق طلقتين"(0). أجيب عن ذلك:

بأن هذا تلبيس منهم، قال الجويني:"وهذا تلبيس لا يتلقى من مثله مأخذ اللسان"(ج).

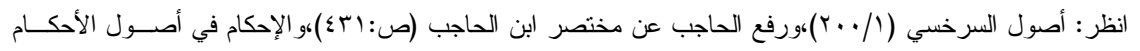

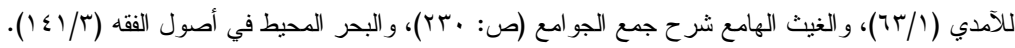

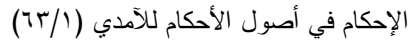

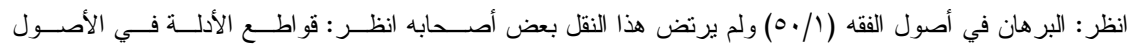

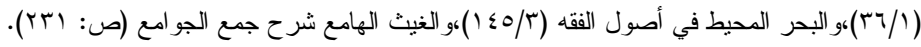

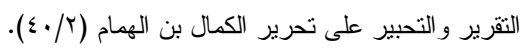

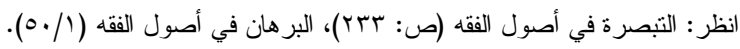

$$
\begin{aligned}
& \text { البرهان في أصول الققه (1/.0). }
\end{aligned}
$$




\section{وجه اعتباره تلبيسا:}

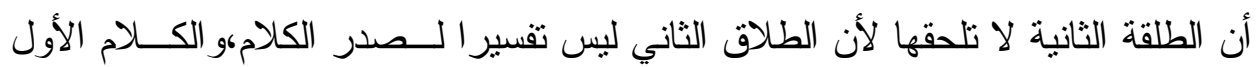

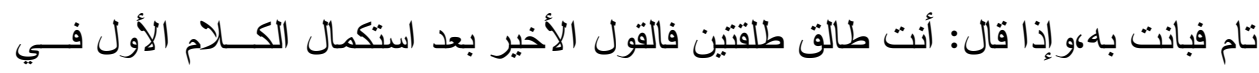
حكم البيان له فكان الكلام بآخره('). تحقيق دعوى التلبيس: أن ما ذكره المانعون من وقوع طلقة و احدة، ليس لأن الو او للترتيب بل لأنها صــادفت

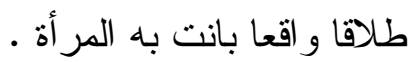

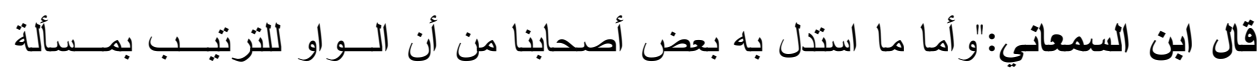

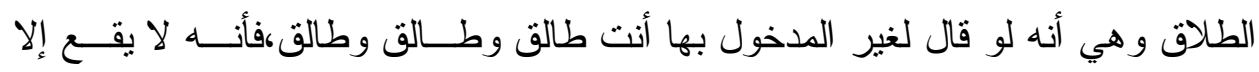

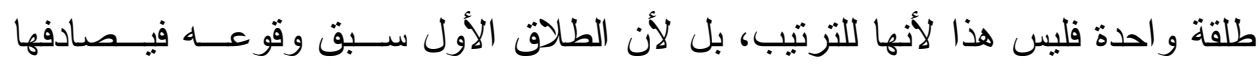

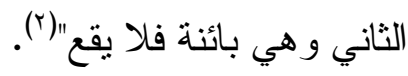

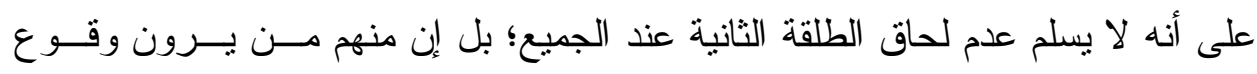
الطلاق طلقتين.

قال أبو يعلى:"وهي توجب الجمع على قول أصحابنا، ولهذا قالو ا فيمن قال لامر أته التي

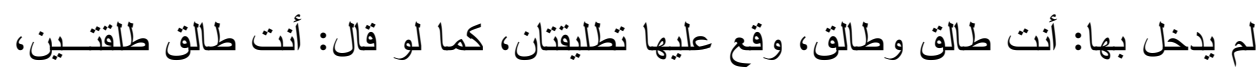
و هو قول أصحاب أبي حنيفة.

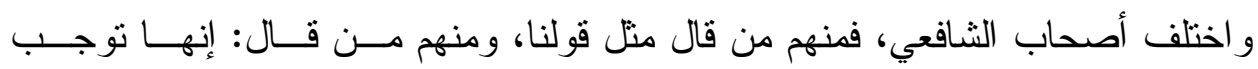
التزتيب

و أما القائلين باللترتيب فإنهم لم يوقعوا الطلقة الثانية لأن الطلقة الأولى وقعت فــــادفتها

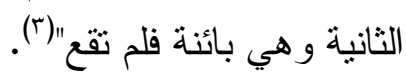


المطلب الثالث: توجه الأمر للمعدوم

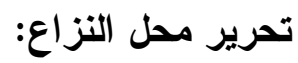

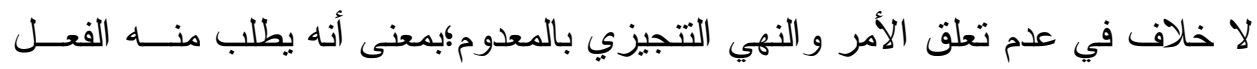

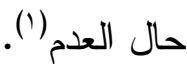
و اختلفو ا في كون المعدوم مأمور ا ومكلفا على تقدير وجوده وتهيئته لفهم الخطاب علـى قولين:

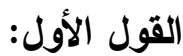

لا يتعلق الأمر و النهي بالمعدوم، وبه فال بعض الحنفية(r)، و المعتزلة(r).

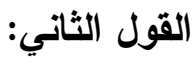

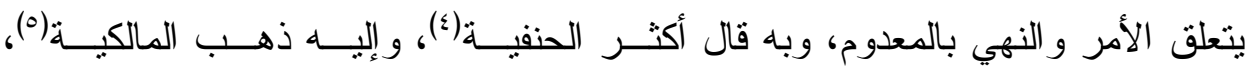

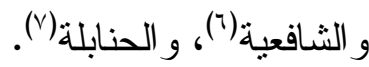
موضع ورود دعوى التلبيس: وردت دعوى التلبيس في معرض مناقشتة القائلين بأن المعـدوم مــأمور علــى تقـدير

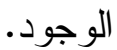

قال الجويني:" إن ظن ظان أن المعدوم مأمور فقد خرج عن حد المعقول وقول القائــلـ

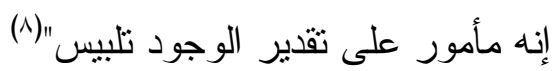

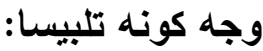

إنه إذا وجد ليس معدوما ولا شك كونه أن الوجود شرط في كون المأمور مأمور|(9)

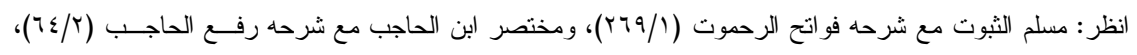

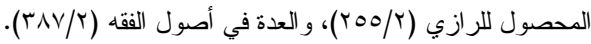

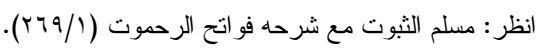

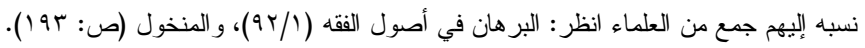

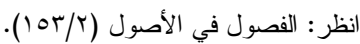

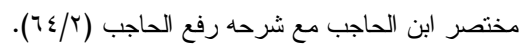

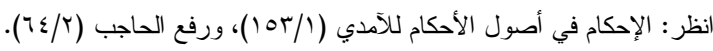

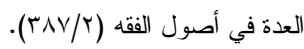

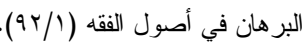
المرجع السابق الصفحة نفسها. (بكان. 


\section{وتحقيق القول في هذه المسألة أن يقال:}

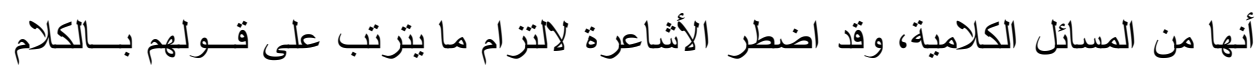
الأزلي؛ فقالو ا: يتعلق الأمر بالمعدوم (').

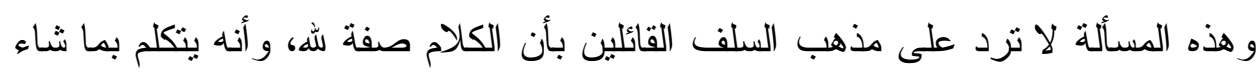

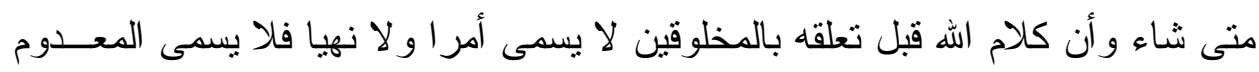

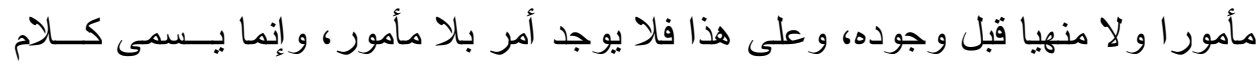

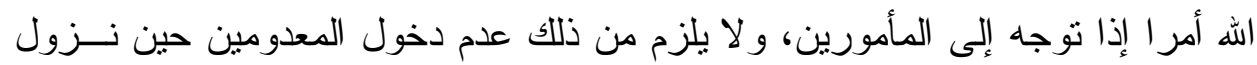

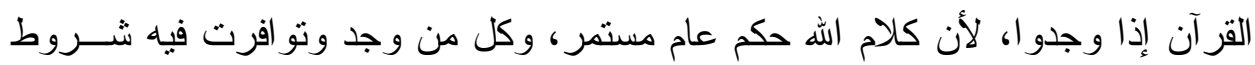
التكليف دخل تحته (r).

المطلب الر ابع: هل الحكم في حق كل شخص ما أدى إليه اجتهاده؟

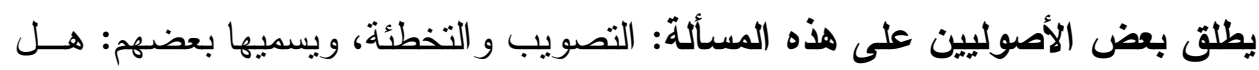

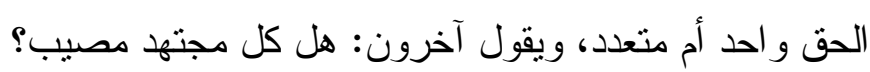
و المسألة لها حالان بالنظر في المجتهَ فئه فيه:

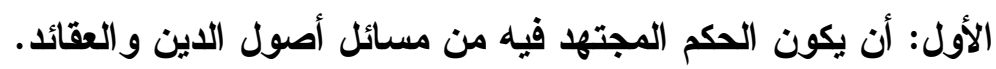

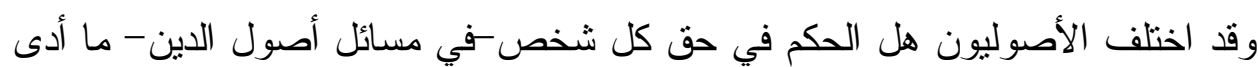
إليه اجتهاده أم أن المصيب والون الأد على قولين:

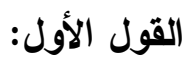

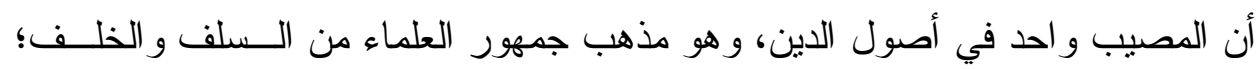

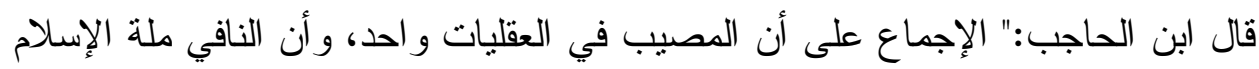

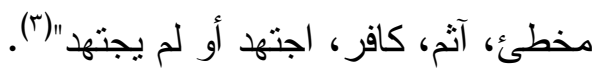

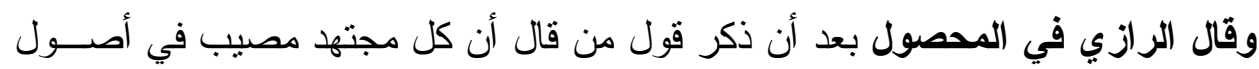

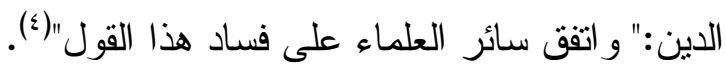
وقال ابن السبكي:"ونحن نتكلم معهما -أبي الجاحظ و العنبري -على سـبيل الاخت التصـار

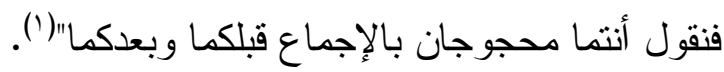

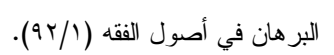

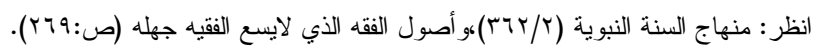

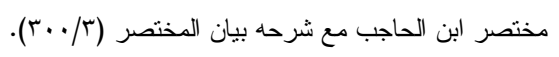

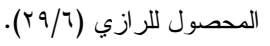


أن كل مجتهذ مصيب و هو ما روي عن عبيد الله بن الحسن العنبري و الجاحظ(؟). قال ابن قدامة:"وزعم الجاحظ: أن مخالف ملة الإسلام إذا نظر، فعزي عن عن درئ درك الحقِّ

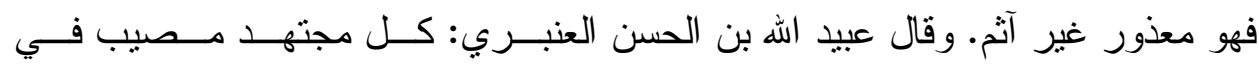

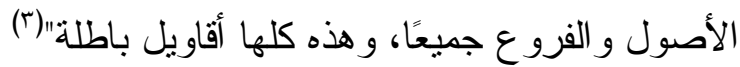
الثاني: أن يكون الحكم المجتهر فيه فرعاً عملياً. فقد اختلف العلماء في الو اقعة التي وقعت ولم يكن عليها نص، أو عليها نص لم يجــــه

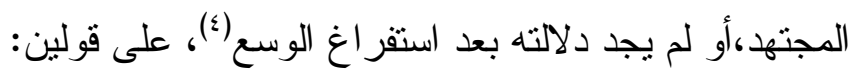

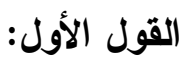

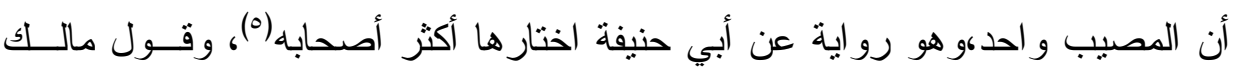

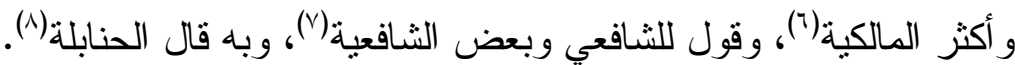
القول الثاني: - الثر الثان

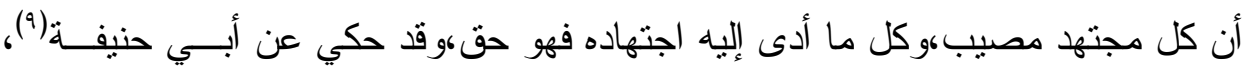

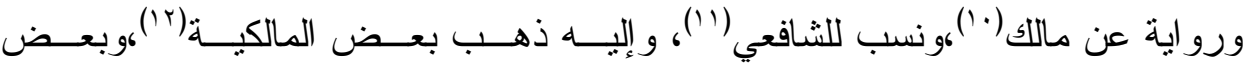

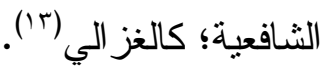

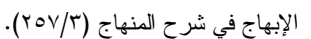

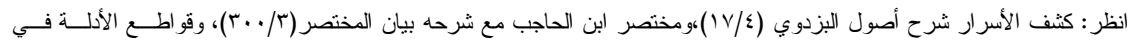

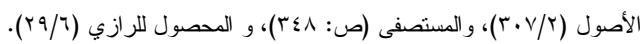

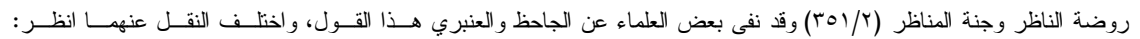

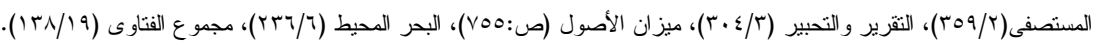

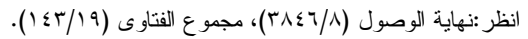

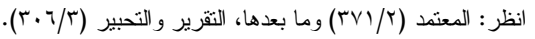

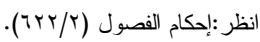

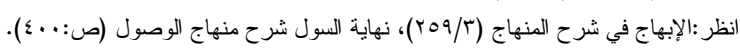

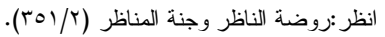

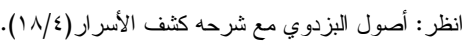

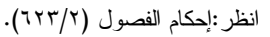

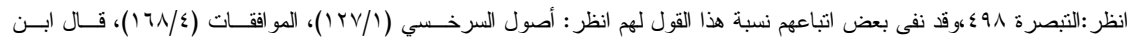

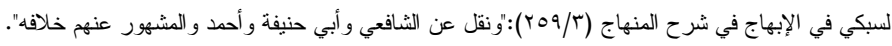

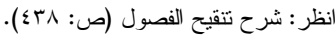

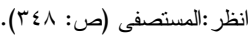




\section{موضع دعوى التلبيس:}

استخل القائلون بأنه ليس لله حكم معين في المسألة بأن الحاكم مأمور بإنفاذ ما يشهـ بـــه

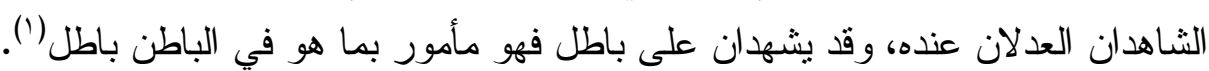

نوقش: بأن استذ لالهم بهذا تلبيس (؟).

وجه كونه تلبيسا:

أن العامل بشهادة الثشاهدين قد عمل بالحق المقطوع الذي أمر بهه، و عملـــهـ بــشهادتهما

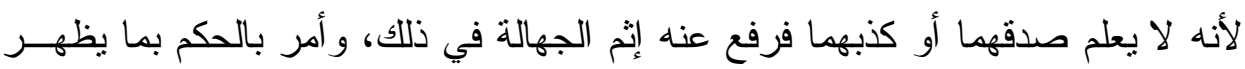

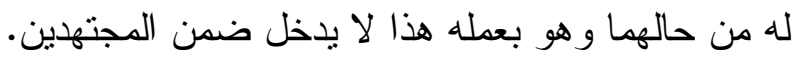

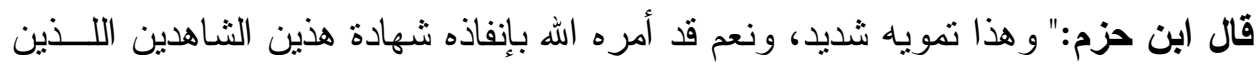

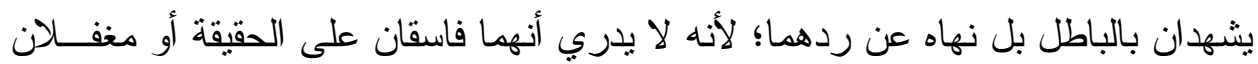

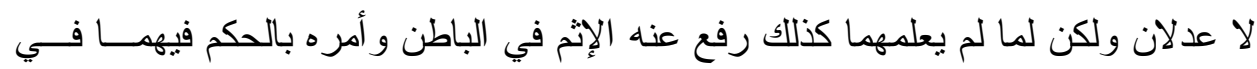

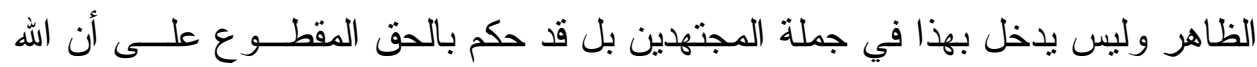

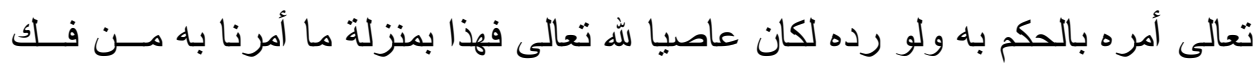

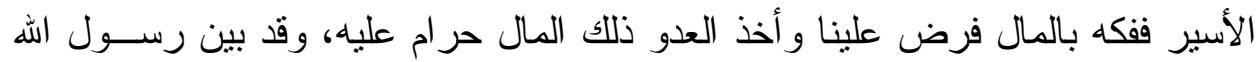

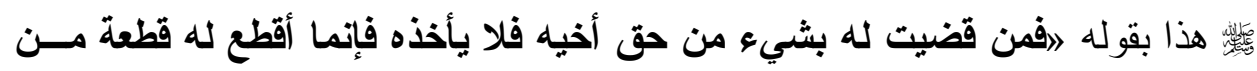

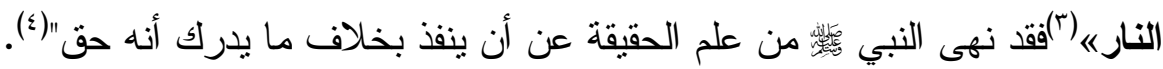
تحقيق القول في دعوى التلبيس:

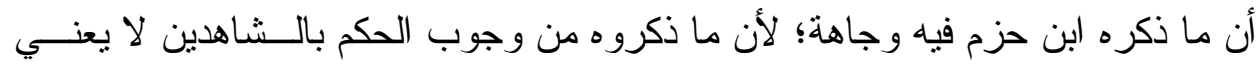

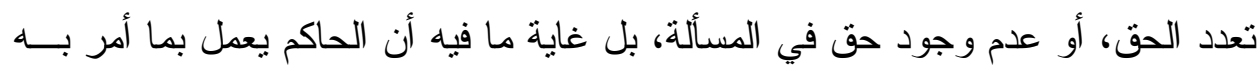
قطعا من الأخذ بشهادة الثاهدين، و العمل بالظاهر .

$$
\text { الظرر : المرجع السابق، الصفحة الأحكام لابن حزم (VN/0). }
$$

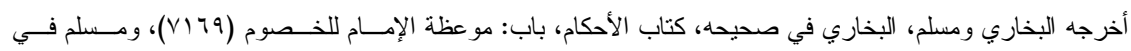

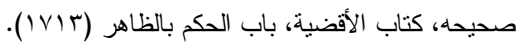

$$
\text { الإحكام في أصول الأحكام لابن حزم (VN/O) }
$$


المطلب الخامس: اعتبار المصير إلى الإجماع تقليدا

عرف التقليد عند الأصوليين بتعريفات كثيرة متقاربة منها:

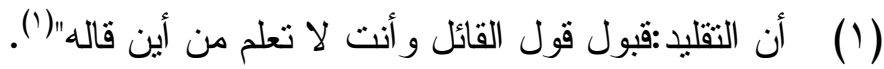

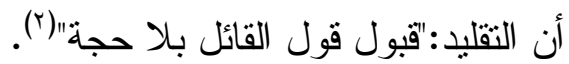

أن التقليد:"أخذ مذهب الغير بلا معرفة دليله"(").

وقد تطرق بعض الأصوليين بعد ذكرهم لتعريف التقليد إلى الخلاف في اعتبار المصبر دلير

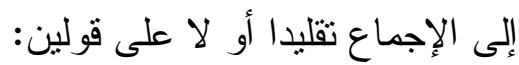
القول الأول: - الأل

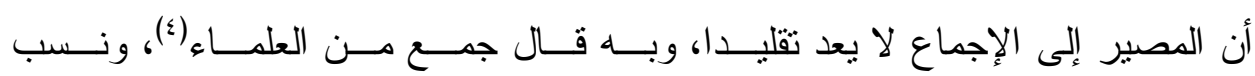
للمتأخرين (0).

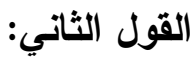

أن المصير إلى الإجماع يعد تقليدا، ونسب لبعض الأصوليين(ج).

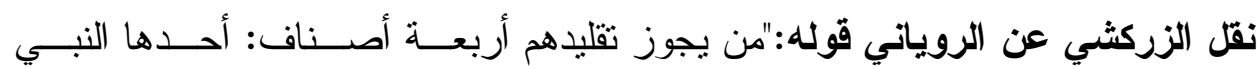

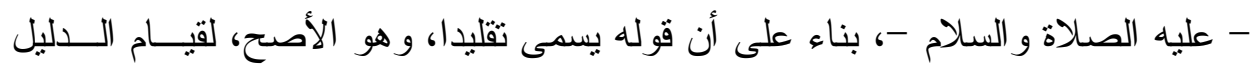
على صدقه، والثاني - المخبر عن الرسول. و الثالث - المجمعون على حكم، فنقليـ لـدهم

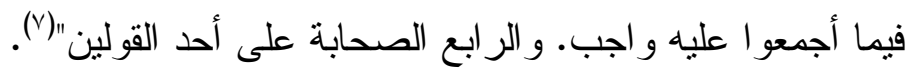

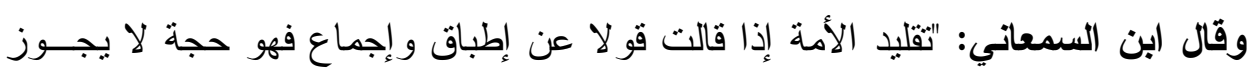

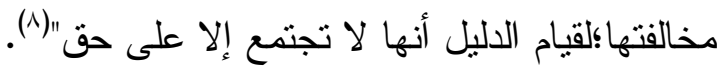

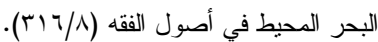

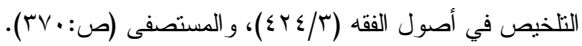

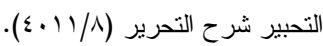

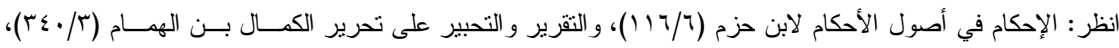

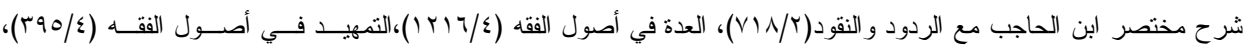

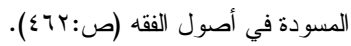

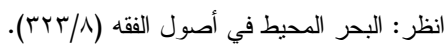

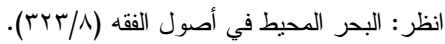

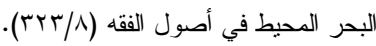

$$
\text { قو اطع الأدلة في الأصول (r/ إصول). }
$$




\section{موضع دعوى التلبيس:}

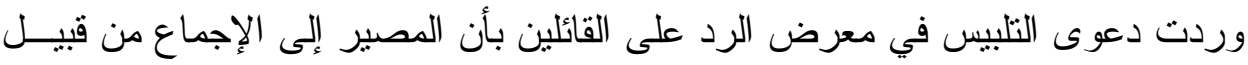

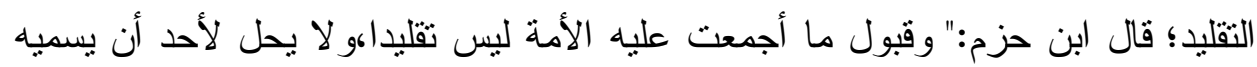

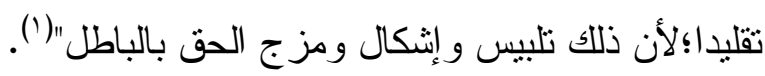
وجه كونه تلبيسا:

أن الإجماع مستتد إلى دليل، وهو دليل في ذاته؛قال ابن حزم:" التقليد على الحقيقة إنمـــا

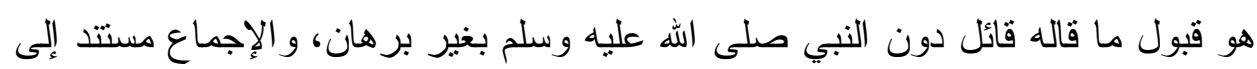

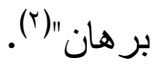
قال أبو يعلــى:"وليس المصير إلى الإجماع تقليد المجمعين، ولكن نفس الإجماع حجة له

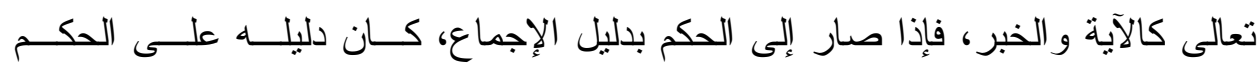

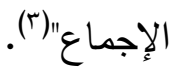
ويمكن أن يناقش: بأن مر اد من عد المصير إنى الإنماع تقليد هو متى عدم مستتد الإجماع. ويمكن الجواب عن هذا: بأن الإجماع لا يمكن أن ينعقد إب هن إلا عن دليل

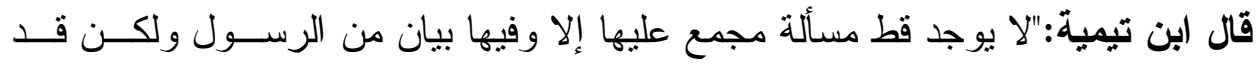

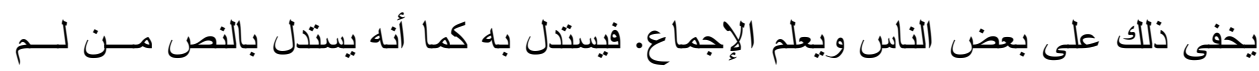

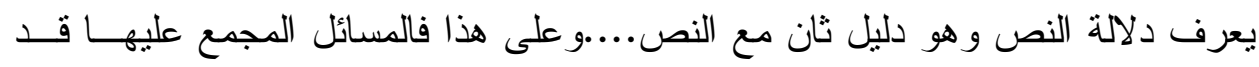

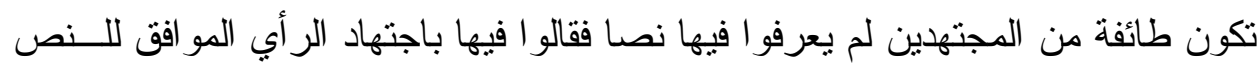
لكن كان النص عند غيرهم.....

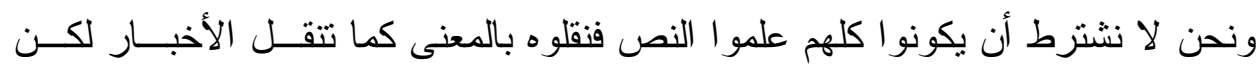

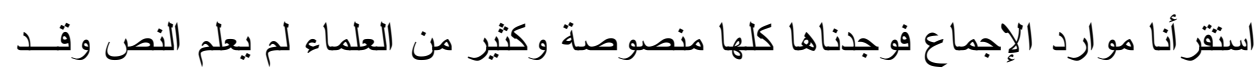

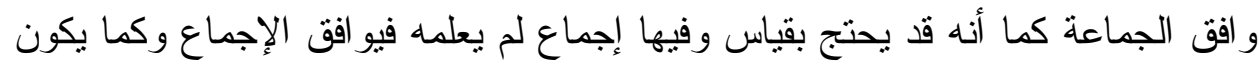

$$
\begin{aligned}
& \text { الإحكام في أصول الأحكام لابن حزم (1) (1) ). } \\
& \text { المرجع السابق، الصفحة نفسها. }
\end{aligned}
$$

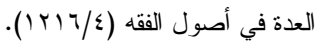


في المسألة نص خاص وقد استدل فيها بعضهم بعموم....و لا بعلم مسألة و احــدة اتفقــو ا

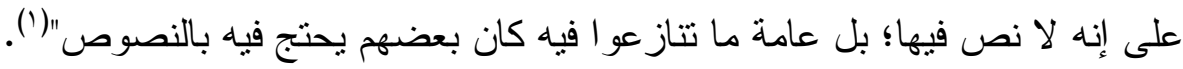
تحقيق القول في دعوى التبليس: الذي يظهر في هذه المسألة أنه لو سمي الإجماع تقلبدا من باب العرف فإنه لا مــشاحة في ذلك، و لا يسمى ذللك تدليسا. قال ابن الحاجب:"التقليد: العمل بقول غيرك من غير حجة وليس الرجوع إلى الرى الرســول

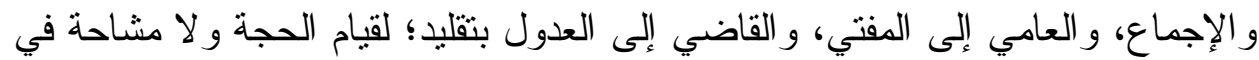

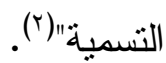

وقال العضد في شرحه على مختصر المنتهى:"ولو سمى ذللك أو بعض ذللك تقليدًا كمـــا

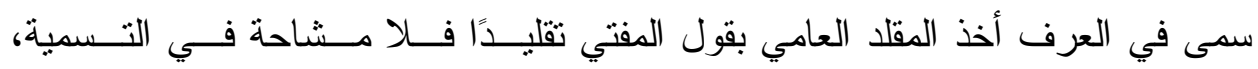

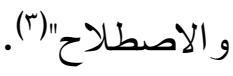

قال الزركشي:"و الخلاف يرجع إلى عبارة"(؛).

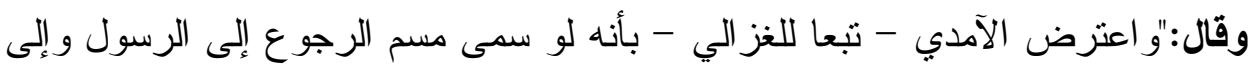
الإجماع و المفتي و الثهود تقليدا بعرف الأستعمال فلا مشاحة في اللفظ "(ه). 


\section{الخاتمة}

الحمد لله على ما أتم و أنعم، و أفضل و أكرم، وفيما يأتي أهم النتائج التي خلصت بها من هذا البحث:

التلبيس في اللغة هو التخليطهو إدخال الأمور ببعضهاهو عدم الإيضاح. • التلبيس اصطلاحا: ستر الحقيقة و إظهار ها بخلاف ما هي عليه. • هناك أمور لابد منها لتحقق التلبيس وهي: صدوره عن ذي بصيرة، وخلط الأمور بعضها ببعض.

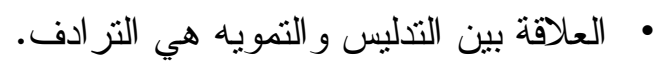

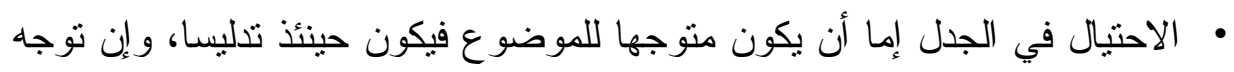

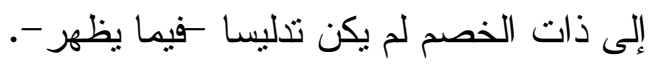
• • من صور التلبيس استخدام المغالطة.

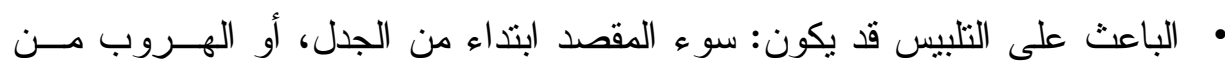
الانقطاع وضعف الحجة.

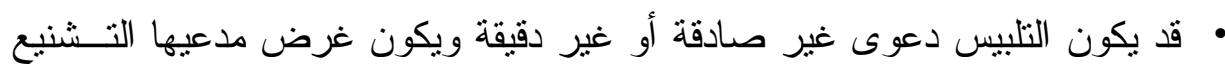

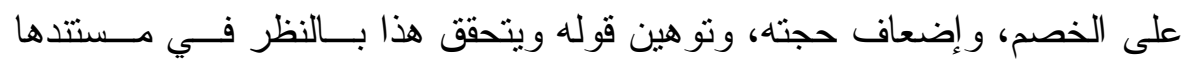
ودليلها وما قامت عليه.

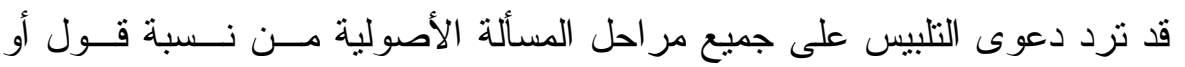
استدلال أو اعتر اض أو مناقثنة أو غير ها.

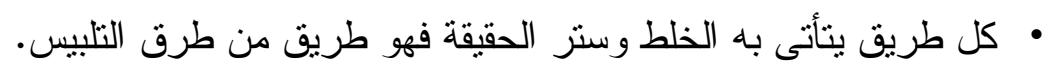

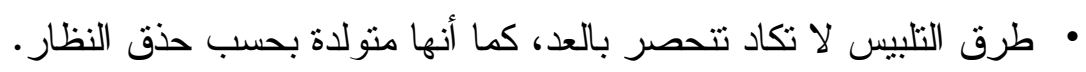
• تأمل قول الخصم يسهم في استكثاف محل التلبيس وموضع التمويه.

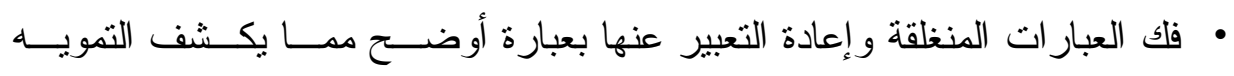
و التلبيس.

• مر اجعة الخصم و الاستفسار منه يسهم في كثف الحقيقة.

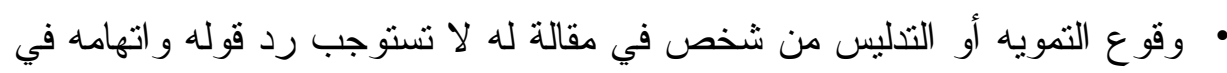

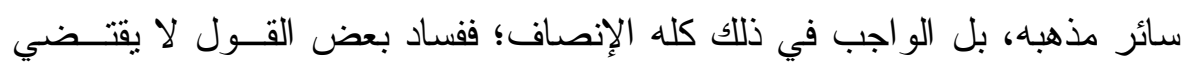
فساد كله. 


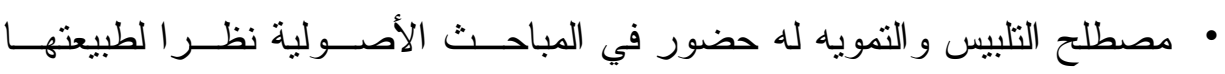
الجدلية.

• • أن لمفهوم التلبيس أنثرا في تضعيف قول الخصم أو التشنيع عليه.

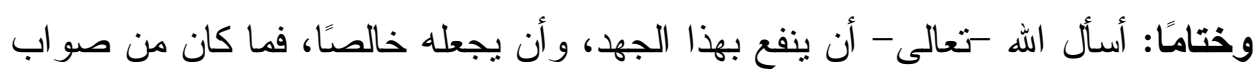

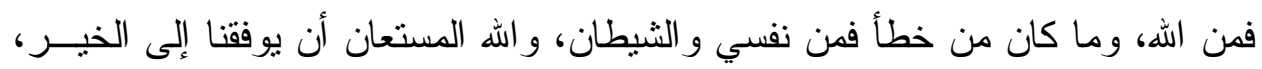
ويهدينا إلى الحق، وصلى الله وسلم على نبينا محمد، وعلى ولى آله وصحبه أجمعين. 


\section{فهرس المراجع}

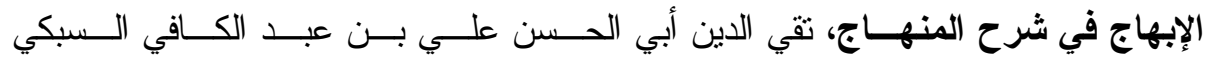

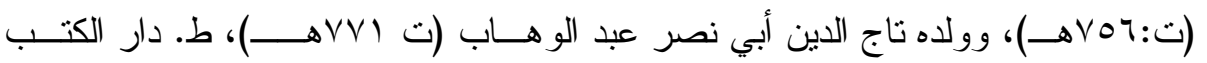

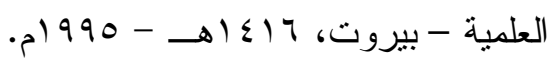

الإحكام في أصول الأحكام، أبي الحسن علي بن أبي علي بن محمد بن سالم الثعلبي الآمدي

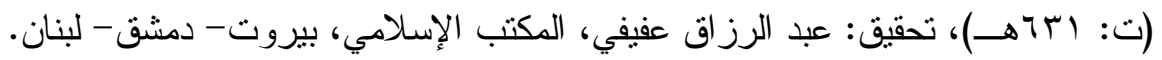

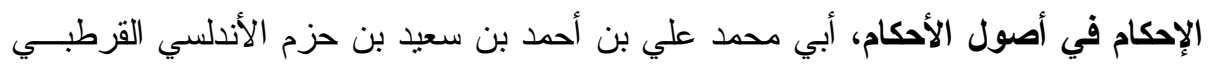

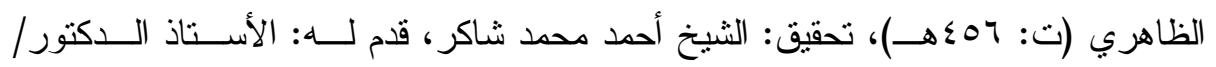
إحسان عباس، دار الآفاق الجديدة، بيروت.

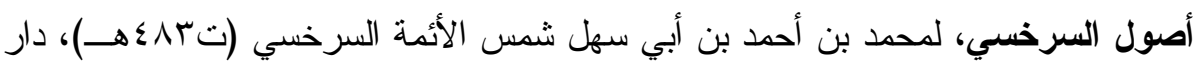
المعرفة - بيروت. - مبرل أصول الفقه الذي لايسع الفقيه جهله، د.عياض بن نامي السلمي، دار التدمريـــة الطبعــة الثالثة 9 أهـ (هـ " الآيات البينات على شرح جمع الجوامع، أحمد بن قاسم العبادي (ت ؟99)، ضبطه وخرج أحاديثه زكريا عمير ات، دار الكتب العلمية، بيروت - لبنان.

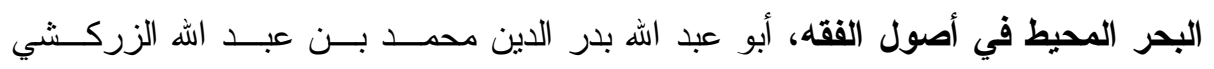

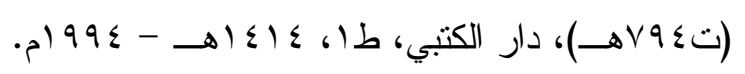

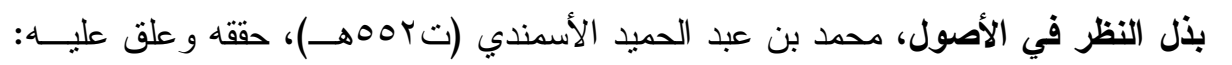

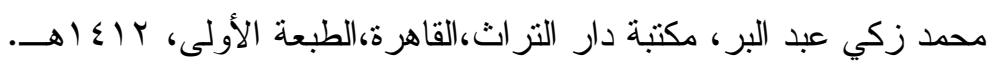

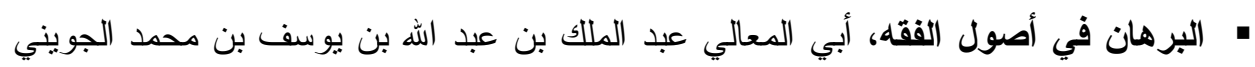

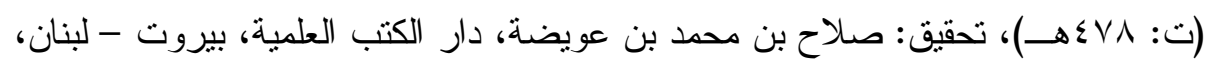

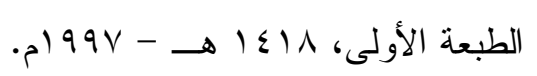
بيان المختصر شرح مختصر ابن الحاجبهمحود بن عبد الرحمن (أبي القاسم) ابن أحمد

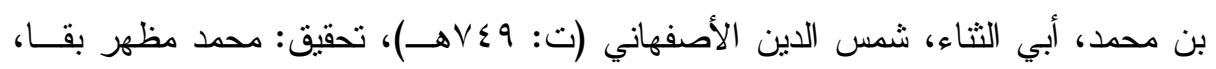

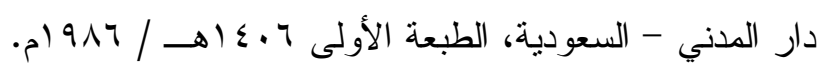




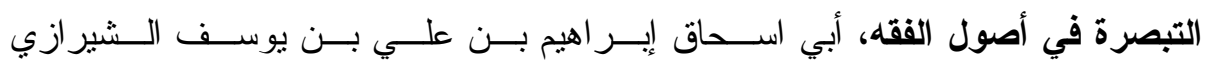

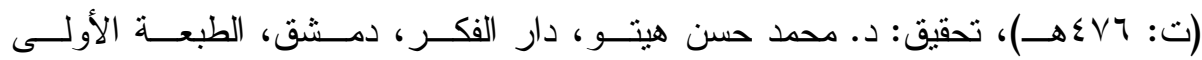
.

التحبير شرح التحرير في أصول الفقه، علاء الدين أبو الحسن علي بن سليمان المرداوي

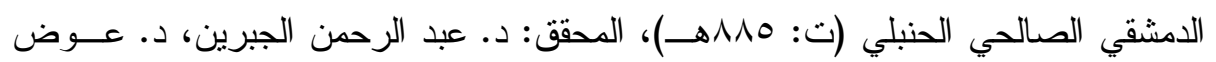

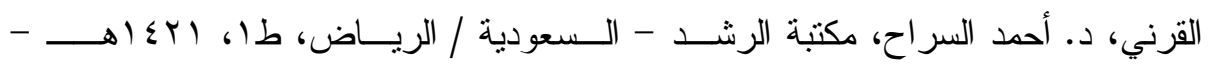
.

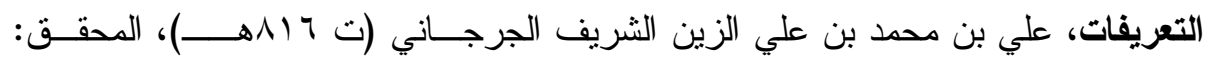

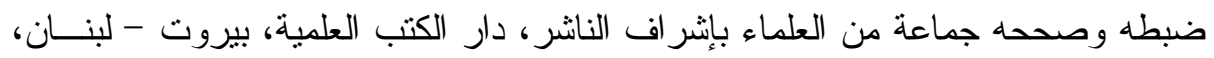
طا، ب.

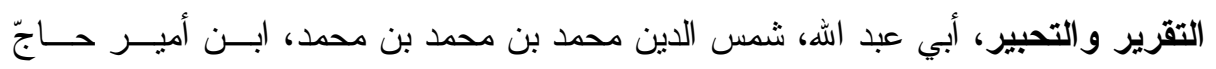

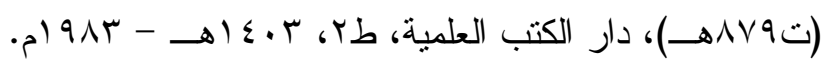

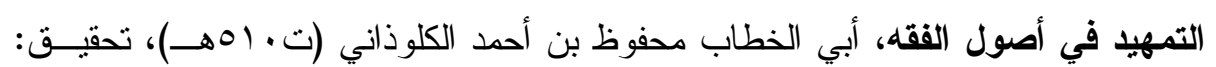
محمد بن علي بن إبر اهيم، مؤسسة الريان، المكتبة المكية.

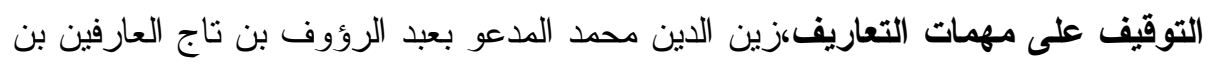

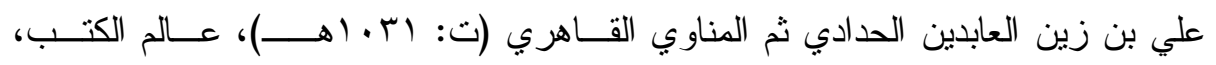

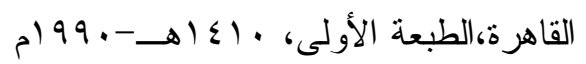

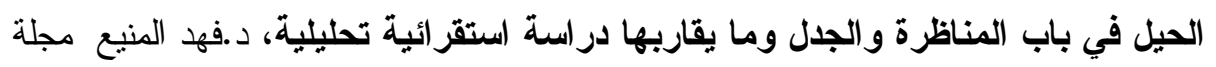

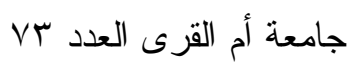
الردود و النقود شرح مختصر ابن الحاجب، محمد بن محمود بن أحمد البــابرنى الحنفـي

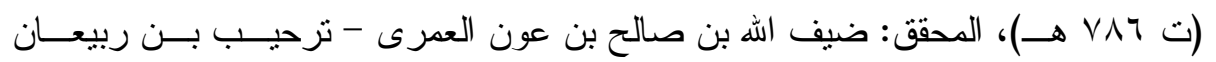

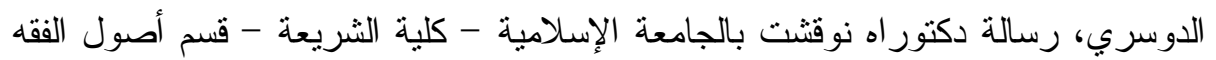

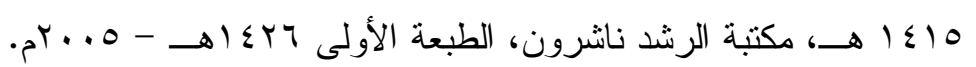

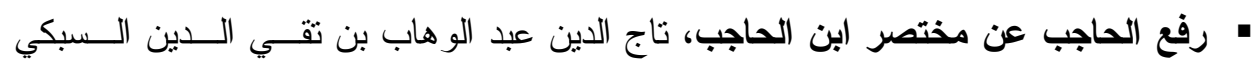

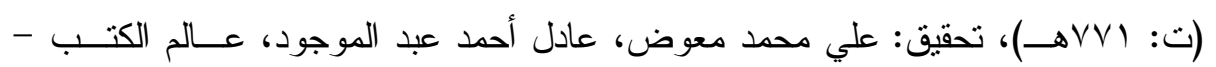

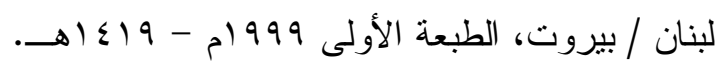


روضة الناظر وجنة المناظر في أصول الفقه على مذهب الإمام أحمد بن حنبل، أبي محدد

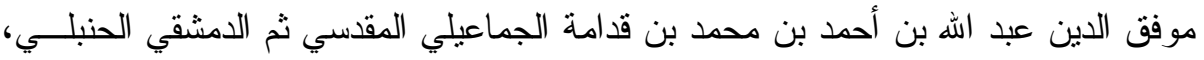

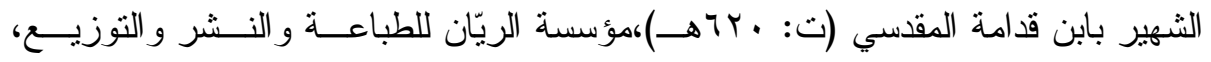

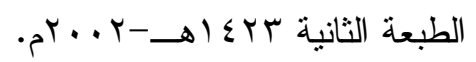

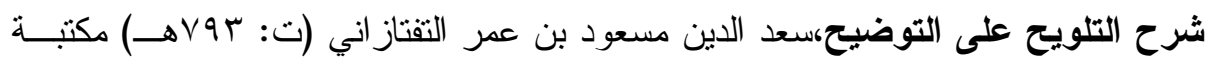
صبيح مصر . مترن

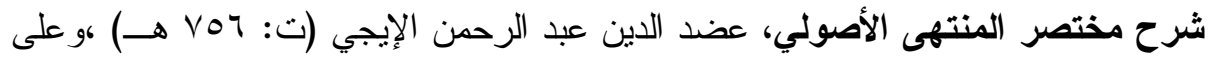

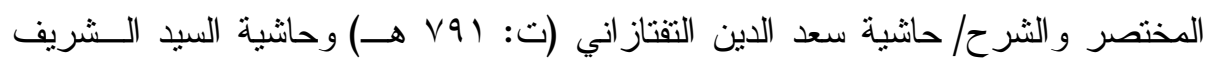
الجرجاني (ت: 17 (1) هـ)، تحقيق: محمد حسن محمد حسن إسماعيل ، دار الكتب العلمية،

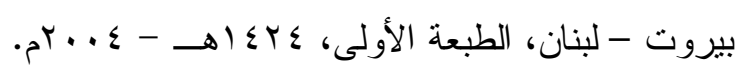

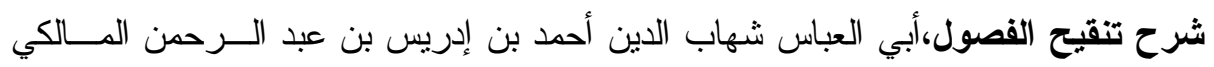

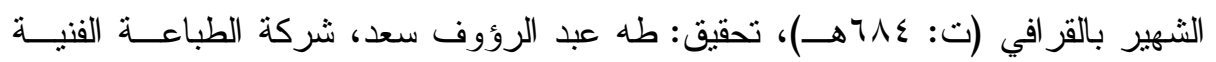

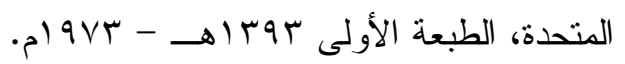

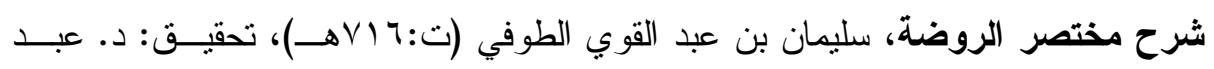

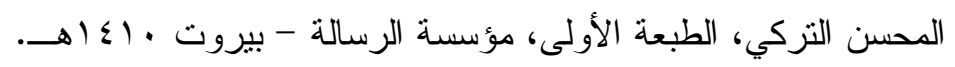

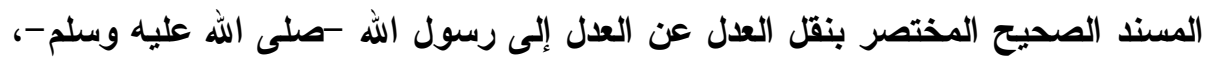

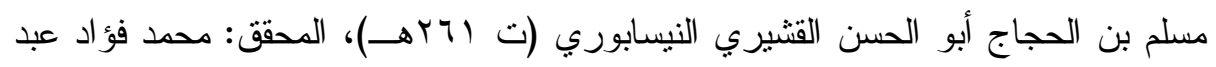
الباقي، دار إحياء التراث العربي - بيروت.

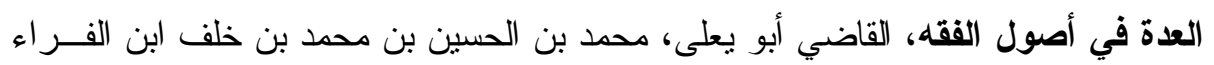

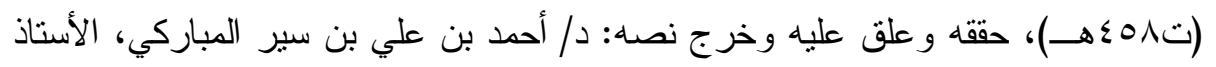

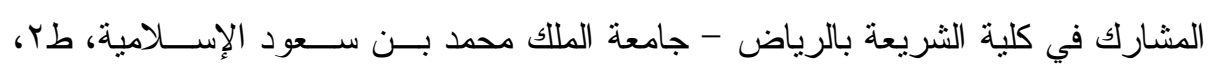

$$
\text { . } 199 .-\rightarrow 1 \leq 1 \text {. }
$$

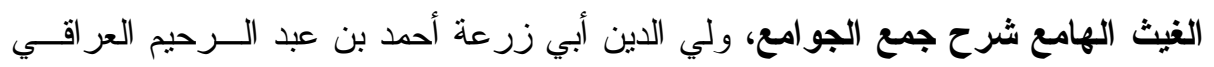

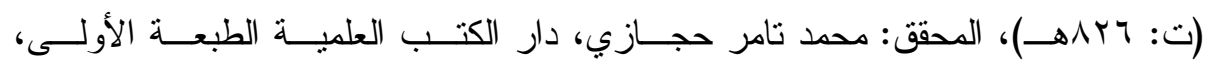

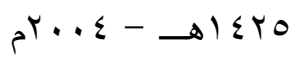

الفصول في الأصول، أحمد بن علي أبو بكر الرازي الجصاص الحنفي (ت: • •rاهـــ)،

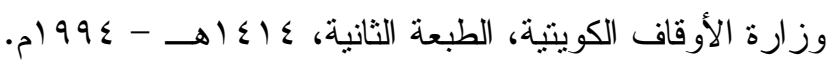




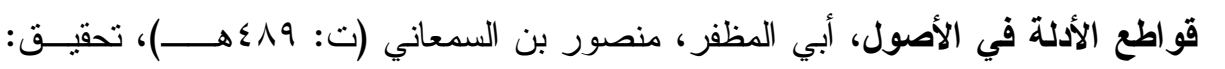

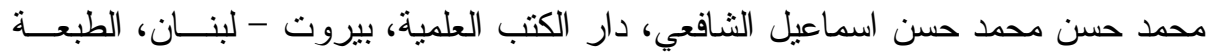

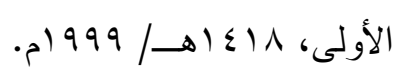

كثف الأسرار شرح أصول البزدوي، عبد العزيز بن أحمد بن محمد، علاء الدين البخاري

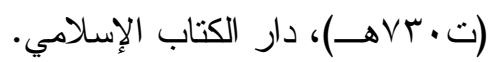

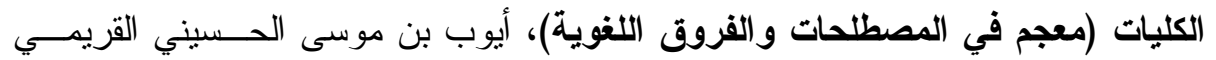

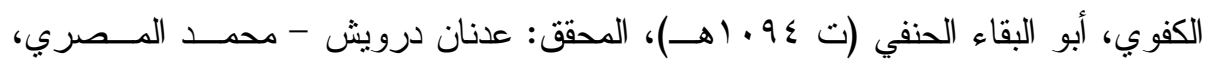
مؤسسة الرسالة - بيروت. البعاء

الكافية في الجدل، أبي المعالي الجويني، المحقق: فوقية حسين محمود، مطبعــة عيـسى لرسى

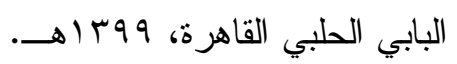

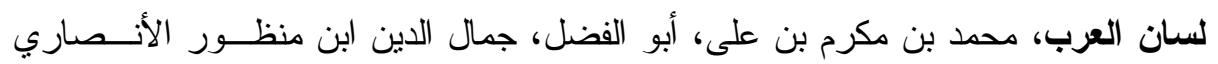

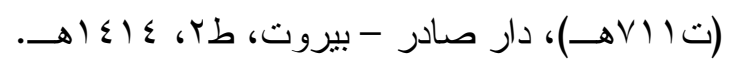

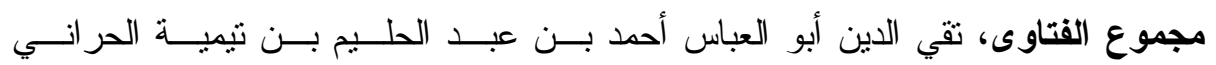

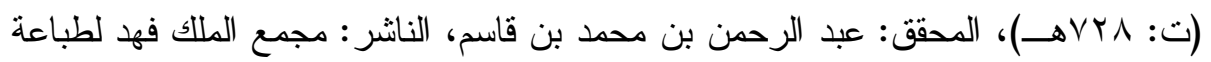

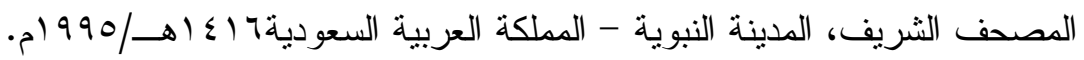

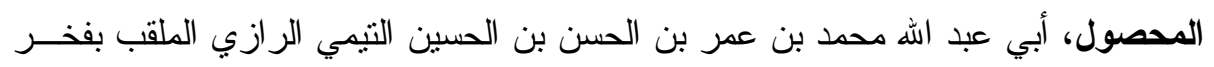

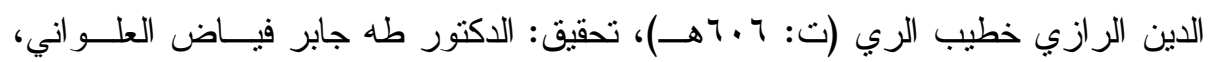

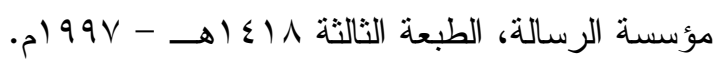

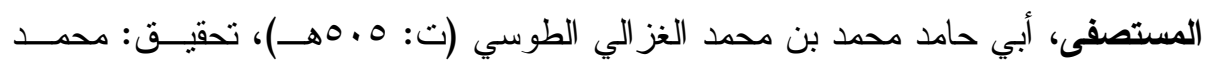

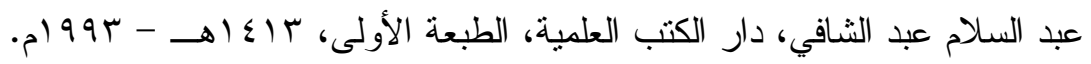

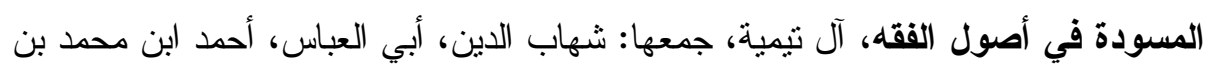

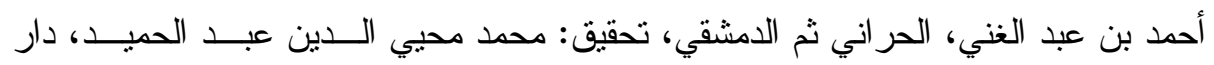

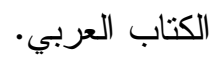

" معجم لغة الفقهاء،حمد رواس قلعجي - حامد صادق قنيبي، دار النفائس للطباعة و النشر

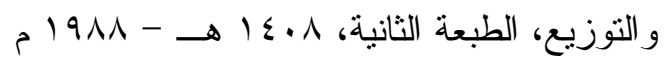


بعم مقاليد العلوم في الحدود والرسوم، عبد الرحمن بن أبي بكر، جال الدين السيوطي

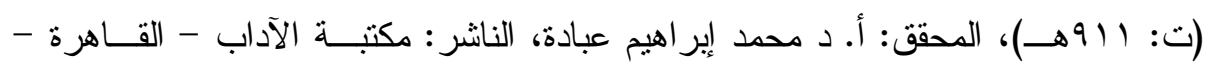

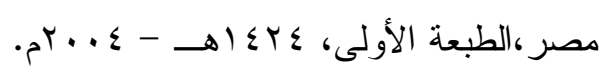

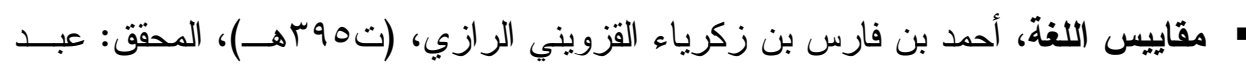

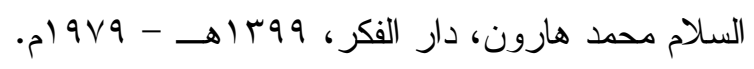

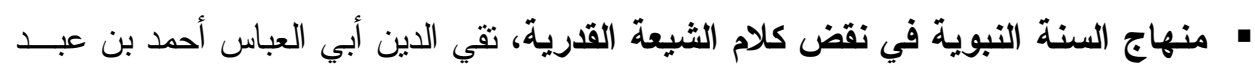

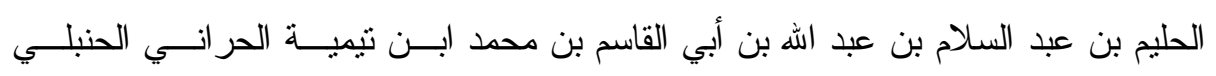

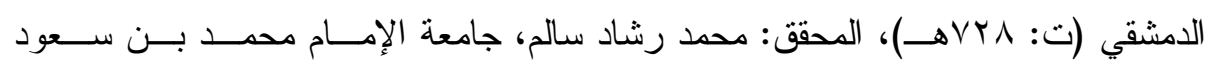

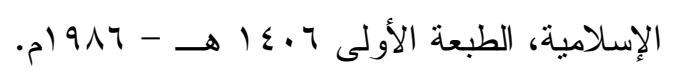

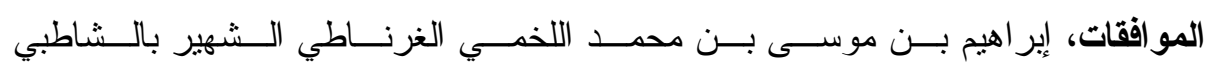

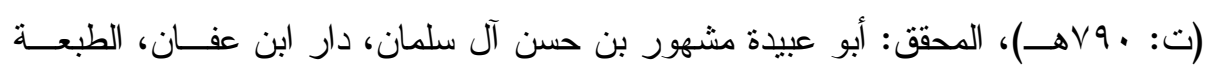

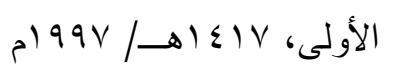

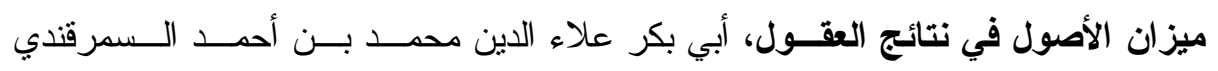

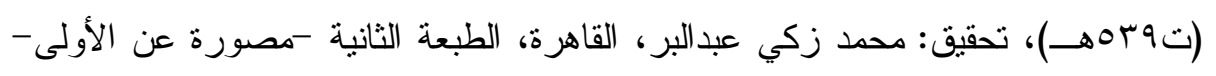

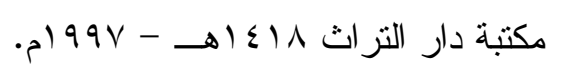

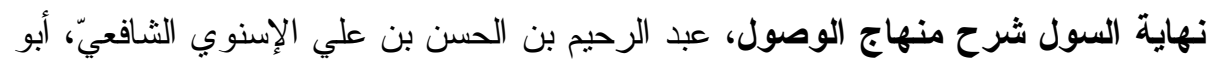

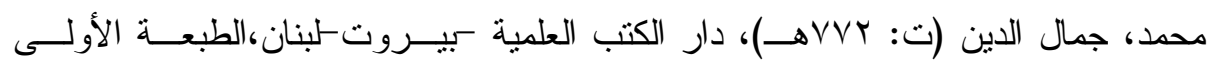

$$
\text { . } 1999-\rightarrow \text { - } 1 \leqslant \text {. }
$$

نهاية الوصول إلى علم الأصـــول، مظفر الدين أحمد بن علي بن الساعاتي، سعد بن غرير

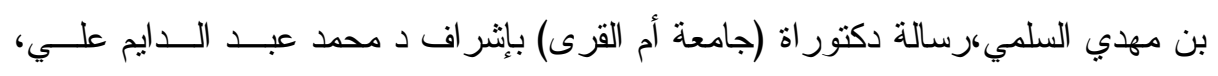

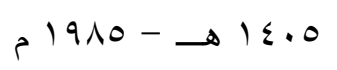

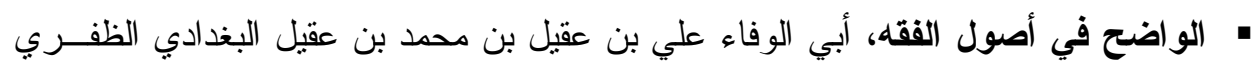

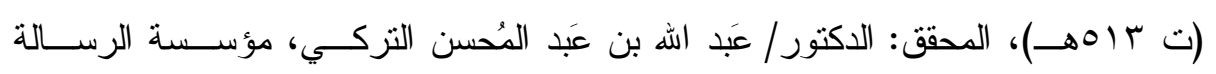

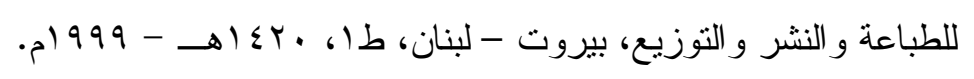

